\title{
Тенденции изучения французского языка в России
}

Александр Арефьев

DOI: 10.30547/mediaalmanah.6.2020.230261

(C) Арефьев Александр Леонардович заместитель руководителя Центра исследования языковой политики и международного образования Государственного института русского языка им. А.С. Пушкина

(г. Москва, Россия), alexander.arefiev@gmail.com
Приоритеты в преподавании иностранных языков в России в силу исторических, политических, экономических причин неоднократно менялись. В XVI-XVII вВ. наиболее активно изучавшимися иностранными языками были латынь и греческий. С начала XVIII в. (на протяжении почти 200 лет) доминирующим иностранным языком в России стал французский (что совпало с эпохой расцвета Франции), причем дети дворян нередко начинали говорить на нем раньше, чем на родном русском языке. А с конца XIX в. в России заметно усилились позиции немецкого языка (равно как и самой Германии в Европе) и немецкий на долгие годы стал самым изучаемым иностранным языком. Так, накануне Первой мировой войны численность российских учебных заведений, в которых преподавался немецкий, значительно превышала численность школ, училищ, гимназий, лицеев с преподаванием французского, английского, испанского языков.

После завершения Второй мировой войны в школах СССР расширилось изучение и использование английского, которое, в условиях глобализации, резко усилилось к концу XX в., и одновременно снизилось количество владевших другими мировыми языками. По результатам последней переписи населения (2010 г.), французский по данному показателю оказался на третьем 


\title{
Les tendances de l'enseignement du français en Russie
}

\author{
Alexandre Aréfiev
}

\begin{abstract}
(C) Arefiev Alexandre
directeur adjoint au Centre de recherches sur la politique linguistique et l'éducation internationale de l'Institut d'État de la langue russe Pouchkine

(Moscou, Russie), alexander.arefiev@gmail.com
\end{abstract}

Pour des raisons historiques, politiques, économiques, les priorités en matière d'enseignement de langues étrangères en Russie ont souvent changé. Si aux XVle et XVIle siècles, les langues les plus étudiées étaient le latin et le grec, au début du XVIIle et durant les 200 années qui suivirent la langue étrangère dominant en Russie fut le français (en corrélation avec l'épanouissement de la France et de son hégémonie en Europe), et les enfants des familles nobles commençaient souvent à parler français avant leur langue maternelle le russe. Cependant, à partir de la fin du XIXe siècle en Russie l'allemand a commencé à consolider ses positions, de même que l'Allemagne elle-même en Europe et l'allemand y est devenu la langue étrangère la plus étudiée. Ainsi, à la veille de la Première guerre mondiale, le nombre d'établissements d'enseignement en Russie proposant des cours d'allemand dépassait largement celui des écoles, instituts et lycée proposant le français, l'anglais ou l'espagnol.

Après la Deuxième guerre mondiale l'enseignement et l'usage de l'anglais s'est répandu en URSS et dans le contexte de mondialisation croissante, ce phénomène s'est renforcé vers la fin du XXe siècle tandis que le nombre de personnes maîtrisant les autres langues internationales diminuait. D'après le dernier recensement (2010) le français figure en troisième place du classement, et le nombre de Russes connaissant le français a diminué de presque 100000 personnes au cours de la décennie précédente (voir tableau 1 )1.

En même temps le nombre d'écoliers et d'étudiants de la RFSFR, puis de la Fédération de Russie, apprenant d'autres langues étrangères que l'anglais a commencé à se réduire encore plus nettement. Par exemple, si pour l'année scolaire 1997-1998 l'allemand était étudié par plus de 4 millions d'élèves, en 2011-2012 ils n'étaient plus que 1,3 million, et 1 million en 2015-2016 (soit 4 fois moins), le français était étudié en 1997-1998 par plus d'un million d'élèves, en 2011-2012 ils n'étaient plus que 352 000, et seulement 275000 en 2015-2016 (voir tableau 2).

Le nombre d'écoles, collèges et lycées proposant des langues autres que l'anglais a aussi diminué (voir tableau 3).

L'anglais s'est confirmé comme première langue étrangère dans les programmes scolaires (voir tableau 4). 
месте, причем число россиян, знающих французский язык, за предшествующее десятилетие снизилось почти на 100 тыс. человек (см. табл. 1)1.

Одновременно численность школьников и студентов РСФСР, а затем и Российской Федерации, изучающих иные, кроме английского, иностранные языки, стала все заметнее снижаться. Например, если в 1997/1998 учебном году немецкий язык в школах РФ изучали более 4 млн детей, в 2011/2012 г. - 1,3 млн, то в 2015/2016 г. лишь 1 млн (т.е. в четыре раза меньше); французский язык в 1997/1998 году учили более 1 млн детей, в 2011/2012 г. - 352 тыс., а в 2015/2016 г. - лишь 275 тыс. (см. табл. 2).

Сокращалось и количество школ, гимназий и лицеев, в которых преподавались иностранные языки, кроме английского (устойчивый рост), китайского и испанского (см. табл. 3).

Английский язык прочно занял место первого иностранного языка в школьных программах (см. табл. 4).

После принятия в 2015 г. решения о постепенном переходе к изучению в российских школах двух иностранных языков (с 2019/2020 уч.г. это обязательно для всех) ситуация с немецким, французским и другими иностранными языками стала меняться к лучшему. Сдвиги в увеличении численности изучающих несколько иностранных языков появились в 2016/2017 учебном году, но «переломным» стал 2018/2019 уч. г., когда впервые за последние два десятилетия резко увеличилась численность изучающих многие иностранные языки и прежде всего - немецкий и французский (см. табл. 5).

С учетом данных по изучению иностранных языков на факультативной основе или в кружках число школьников, лицеистов и гимназистов, изучавших французский язык, выросло значительно, увеличилось и количество общеобразовательных организаций с преподаванием французского языка (см. табл. 6).
Увеличение численности изучавших французский произошло прежде всего за счет его изучения как второго иностранного языка (см. табл. 7). Больше всего изучавших французский язык в 2018/2019 учебном году было в Московском регионе (см. табл. 8).

Общие тенденции изменения численности изучавших иностранные языки в общеобразовательных организациях России в период с 1997/1998 по 2018/2019 учебные годы включительно отражены на рисунке 12 .

Французский язык сегодня учат 3,4\% всех российских школьников, изучающих иностранные языки, что несколько ниже соответствующего показателя 2007/2008 учебного года и вдвое ниже, чем в 1997/1998 учебном году (см. рис. 2).

Одновременно сувеличением числа российских школьников, гимназистов, лицеистов, изучавших французский язык как второй иностранный, отмечается сокращение числа изучающих его углубленно, особенно в младших классах (см. табл. 9)3.

Сокращается в последние годы и число школьников, сдающих ЕГЭ по французскому языку (см. табл. 10)4. Тем не менее результаты единых государственных экзаменов по иностранным языкам в России в 20122019 гг. подтверждают, что французский язык неизменно занимает третье место по числу участников этих экзаменов, хотя достаточно высокие средние тестовые баллы по французскому языку в 2019 г. несколько снизились (см. табл. 11)5.

В основной части единого государственного экзамена по иностранным языкам 2019 г. приняли участие 77,5 тыс. человек, из них экзамен по английскому языку сдавали 95,8\% участников (в 2018 г. - 96,7\%), по немецкому языку - 1,6\% (в 2018 г. - 1,9\%), по французскому языку - 1,0\% (в 2018 г. $1,2 \%$ ) и по испанскому языку - 0,2\% (аналогично показателю 2018 г.).

Доля высокобалльных (от 81 до 100 баллов) работ составила в 2019 г. по английскому языку - 42,73\%, по немецкому 
Après la décision prise en 2015 de passer progressivement à l'étude de deux langues étrangères dans les écoles de Russie (obligatoire pour tous à partir de l'année scolaire 2019-2020), la situation de l'allemand, du français et d'autres langues s'est améliorée. Une avancée notable dans le nombre d'élèves étudiant des langues étrangères s'est manifestée à partir de 2016-2017 mais l'année charnière a été 2018-2019 quand pour la première fois depuis deux décennies le nombre d'élèves apprenant plusieurs langues, et avant tout l'allemand et le français, a augmenté (voir tableau 5).

Si on prend en compte les données sur l'étude facultative des langues étrangères ou en groupe, le nombre d'écoliers, collégiens et lycéens étudiant le français a encore plus augmenté, de même qu'a augmenté le nombre d'établissements d'enseignement général dispensant des cours de français (voir tableau 6).

L'augmentation du nombre d'élèves apprenant le français est surtout due au renforcement de son statut de deuxième langue vivante (voir tableau 7)

Le plus grand nombre d'élèves apprenant le français en 2018-2019 est enregistré dans la région de Moscou (voir tableau 8).

Les tendances générales d'évolution du nombre d'élèves apprenant des langues étrangères dans les établissements d'enseignement général de Russie pendant la période allant de l'année 1997-1998 à 2018-2019 sont exprimées dans les données du schéma 1 ci-dessous².

Le français est aujourd'hui étudié par 3,4\% du total des écoliers russes apprenant des langues étrangères, ce qui est légèrement inférieur aux données de 20072008 et deux fois plus bas que pour l'année 1997-1998 (voir schéma 2 ci-dessous).

En même temps que le nombre d'écoliers, de collégiens et de lycées russes apprenant le français comme deuxième langue étrangère augmente, on note une diminution du nombre de ceux qui l'étudient de manière approfondie, surtout dans les petites classes (voir tableau 9) ${ }^{3}$.

Ces dernières années le nombre d'écoliers passant l'épreuve de français à l'examen de fin de scolarité (EGE) se réduit également (voir tableau 10)4.

Cependant, les résultats des épreuves de langues étrangères de l'examen de fin de scolarité en Russie pour les années 2012-2019 confirment que le français occupe invariablement la troisième place en nombre d'élèves passant ces épreuves, bien que les notes relativement élevées en moyenne pour le français aient un peu baissé en 2019 (voir tableau 11) $)^{5}$.

Au total 77500 élèves ont participé aux épreuves principales de langue étrangère de l'examen de fin de scolarité en 2019, parmi eux 95,8\% ont passé l'épreuve d'anglais (contre $96,7 \%$ en 2018), 1,6\% celle d'allemand (1,9\% en 2018), $1,0 \%$ celle de français ( $1,2 \%$ en 2018 ) et $0,2 \%$ celle d'espagnol (idem en 2018 ).

La part de bons résultats (de 81 à 100 points) an anglais était de $42,73 \%$ en 2019 , en allemand de $42,1 \%$, en français de $39,3 \%$, en espagnol de $45,5 \%$, en chinois de $29,2 \%$. Ceux qui ont pu obtenir la note maximale de 100 points en langue étrangère était peu nombreux en 2019 (15 élèves en anglais, 3 en allemand, 2 en français et 1 en chinois).

À l'heure actuelle on compte également en Russie 23 écoles, collèges, lycées, centres d'enseignement bilingues où certaines matières sont dispensées en français (tous sont des établissements d'enseignement général spécialisés avec étude approfondie du français). Parmi eux citons les collèges $n^{\circ} 39$ et 110 
Таблица 1. Владение населением России иностранными языками

\begin{tabular}{|c|c|c|c|c|c|}
\hline \multirow[t]{2}{*}{ Язык } & \multicolumn{2}{|c|}{$2002 \mathrm{r}}$. & \multicolumn{2}{|c|}{$2010 \mathrm{r}}$. & \multirow{2}{*}{$\begin{array}{c}\text { Изменения, } \\
\text { млн чел. }\end{array}$} \\
\hline & $\begin{array}{c}\text { Кол-во, } \\
\text { млн чел. }\end{array}$ & $\begin{array}{c}\text { Доля, } \\
\%\end{array}$ & $\begin{array}{c}\text { Кол-во, } \\
\text { млн чел. }\end{array}$ & $\begin{array}{c}\text { Доля, } \\
\%\end{array}$ & \\
\hline Английский & 6955,3 & 4,8 & 7574,3 & 5,5 & $+619,0$ \\
\hline Немецкий & 2895,1 & 2,0 & 2070,0 & 1,5 & $-825,1$ \\
\hline Французский & 705,2 & 0,5 & 616,4 & 0,4 & $-98,8$ \\
\hline Испанский & 111,9 & 0,08 & 152,1 & 0,1 & $+40,2$ \\
\hline Итальянский & 54,2 & 0,04 & 83,2 & 0,06 & $+29,0$ \\
\hline Китайский & 59,2 & 0,04 & 70,7 & 0,05 & $+11,5$ \\
\hline $\begin{array}{l}\text { Всего указавших } \\
\text { владение } \\
\text { различными языками }\end{array}$ & 143746,2 & 100,0 & 138312,5 & 100,0 & $-5433,7$ \\
\hline
\end{tabular}

Таблица 2. Количество изучавших иностранные языки как учебный предмет в школах, гимназиях и лицеях России в 2011/2012 -2015/2016 уч гг.

\begin{tabular}{|l|r|r|c|}
\hline \multicolumn{1}{|c|}{ Иностранный язык } & $\mathbf{2 0 1 1 / 2 0 1 2 ~ у ч . ~ г . ~}$ & $\mathbf{2 0 1 5 / 2 0 1 6}$ уч. г. & $\begin{array}{c}\text { Изменения, } \\
\mathbf{2 0 1 1 / 2 0 1 2 - 2 0 1 6 / 2 0 1 7}\end{array}$ \\
\hline Английский & 10033400 & 11381929 & +2784704 \\
\hline Немецкий & 1305393 & 1004990 & -299432 \\
\hline Французский & 352739 & 275047 & -46429 \\
\hline Испанский & 14751 & 19473 & +8056 \\
\hline Китайский & 10476 & 16181 & +8804 \\
\hline Итальянский & 2604 & 2549 & +877 \\
\hline Арабский & 19472 & 3932 & +17567 \\
\hline Другие & 20881 & 17102 & -702 \\
\hline
\end{tabular}

Таблица 3. Количество школ, гимназий и лицеев, в которых изучались как учебный предмет различные иностранные языки в 2011/2012-2015/2016 уч. гг.

\begin{tabular}{|l|c|c|c|}
\hline $\begin{array}{c}\text { Иностранный } \\
\text { язык }\end{array}$ & $\mathbf{2 0 1 1 / 2 0 1 2 ~ у ч . ~ г . ~}$ & $\mathbf{2 0 1 5 / 2 0 1 6}$ уч. г. & $\begin{array}{c}\text { Изменения, } \\
\mathbf{2 0 1 / 2 - 2 0 1 5 / 2 0 1 6}\end{array}$ \\
\hline Английский & 33423 & 37518 & +4095 \\
\hline Немецкий & 19451 & 14773 & -4678 \\
\hline Французский & 3881 & 2752 & -1129 \\
\hline Испанский & 122 & 135 & +13 \\
\hline Китайский & 75 & 111 & +36 \\
\hline Арабский & 191 & 43 & -148 \\
\hline Итальянский & 36 & 26 & -10 \\
\hline
\end{tabular}


НАУЧНЫЕ ДОКЛАДЫ

Tableau 1 - Connaissance des principales langues étrangères par la population russe

\begin{tabular}{|l|r|r|r|r|c|}
\hline \multirow{2}{*}{ Langues } & \multicolumn{2}{|c|}{ 2002 } & \multicolumn{2}{c|}{ 2010 } & Variations, en \\
\cline { 2 - 6 } & $\begin{array}{c}\text { Nombre de } \\
\text { personnes } \\
\text { maîtrisant la } \\
\text { langue, en } \\
\text { millions }\end{array}$ & Part en \% & $\begin{array}{c}\text { Nombre de } \\
\text { personnes } \\
\text { maîtrisant la } \\
\text { langue, en } \\
\text { millions }\end{array}$ & Part en \% & \\
\hline Anglais & 6955,3 & 4,8 & 7574,3 & 5,5 & $+619,0$ \\
\hline Allemand & 2895,1 & 2,0 & 2070,0 & 1,5 & $-825,1$ \\
\hline Français & 705,2 & 0,5 & 616,4 & 0,4 & $-98,8$ \\
\hline Espagnol & 111,9 & 0,08 & 152,1 & 0,1 & $+40,2$ \\
\hline Italien & 54,2 & 0,04 & 83,2 & 0,06 & $+29,0$ \\
\hline Chinois & 59,2 & 0,04 & 70,7 & 0,05 & $+11,5$ \\
\hline $\begin{array}{l}\text { Total des personnes } \\
\text { ayant mentionné la } \\
\text { maîtrise de différentes } \\
\text { langues }\end{array}$ & 143746,2 & 100,0 & 138312,5 & 100,0 & $-5433,7$ \\
\hline
\end{tabular}

Tableau 2 - Nombre d'élèves apprenant les langues étrangères en tant que matière dans les écoles, collèges et lycées en Russie en 2011-2012 et 2015-2016.

\begin{tabular}{|l|r|r|c|}
\hline \multicolumn{1}{|c|}{$\begin{array}{c}\text { Langues /années } \\
\text { scolaires }\end{array}$} & $\mathbf{2 0 1 1 - 2 0 1 2}$ & $\mathbf{2 0 1 5 - 2 0 1 6}$ & $\begin{array}{c}\text { Variations pour les années } \\
\mathbf{2 0 1 1 / 1 2 - 2 0 1 6 / 2 0 1 7}\end{array}$ \\
\hline Anglais & 10033400 & 11381929 & +2784704 \\
\hline Allemand & 1305393 & 1004990 & -299432 \\
\hline Français & 352739 & 275047 & -46429 \\
\hline Espagnol & 14751 & 19473 & +8056 \\
\hline Chinois & 10476 & 16181 & +8804 \\
\hline Italien & 2604 & 2549 & +877 \\
\hline Arabe & 19472 & 3932 & +17567 \\
\hline Autres & 20881 & 17102 & -702 \\
\hline
\end{tabular}

Tableau 3 - Nombre d'écoles, collèges et lycées dans lesquels différentes langues étrangères sont étudiées en tant que matière scolaire en 2011-2012 et 2015-2016

\begin{tabular}{|l|r|r|c|}
\hline $\begin{array}{c}\text { Langues /années } \\
\text { scolaires }\end{array}$ & $\mathbf{2 0 1 1 - 2 0 1 2}$ & $\mathbf{2 0 1 5 - 2 0 1 6}$ & $\begin{array}{c}\text { Variations pour les années } \\
\mathbf{2 0 1 1 / 1 2 - 2 0 1 6 / 2 0 1 7}\end{array}$ \\
\hline Anglais & 33423 & 37518 & +4095 \\
\hline Allemand & 19451 & 14773 & -4678 \\
\hline Français & 3881 & 2752 & -1129 \\
\hline Espagnol & 122 & 135 & +13 \\
\hline Chinois & 75 & 111 & +36 \\
\hline Arabe & 191 & 43 & -148 \\
\hline Italien & 36 & 26 & -10 \\
\hline
\end{tabular}


Таблица 4. Показатели изучения иностранных языков в качестве первого и второго (а также третьего и других) языков в 2015/2016 уч. г. в школах, гимназиях и лицеях России, кол-во чел.

\begin{tabular}{|l|c|c|c|c|}
\hline $\begin{array}{c}\text { Иностранный } \\
\text { язык }\end{array}$ & Всего изучали & $\begin{array}{c}\text { Как 1-й } \\
\text { иностранный язык }\end{array}$ & $\begin{array}{c}\text { Как 2-й и 3-й } \\
\text { иностранный язык }\end{array}$ & $\begin{array}{c}\text { Доля } \\
\text { изучавших } \\
\text { иностранный язык } \\
\text { как 2-й и 3-й }\end{array}$ \\
\hline Английский & 11381929 & 11222124 & 159805 & 1,4 \\
\hline Немецкий & 1004990 & 811829 & 193161 & 19,2 \\
\hline Французский & 275047 & 143917 & 131130 & 47,7 \\
\hline Испанский & 19473 & 8108 & 11365 & 58,4 \\
\hline Китайский & 16181 & 4661 & 111520 & 71,2 \\
\hline Арабский & 3932 & 3069 & 863 & 21,9 \\
\hline Итальянский & 2549 & 638 & 1911 & 75,0 \\
\hline Другие & 17102 & 3920 & 13182 & 77,1 \\
\hline
\end{tabular}

Таблица 5. Изучение иностранных языков как учебного предмета в школах, гимназиях и лицеях России в 2016/2017 - 2018/2019 уч. гг., кол-во чел.

\begin{tabular}{|l|c|c|c|}
\hline $\begin{array}{c}\text { Иностранный } \\
\text { язык }\end{array}$ & $\mathbf{2 0 1 6 / 2 0 1 7}$ уч. г.* & $\mathbf{2 0 1 8 / 2 0 1 9}$ уч. г. & $\begin{array}{c}\text { Изменения } \\
\text { 3a 2016/2017-2018/2019 }\end{array}$ \\
\hline Английский & 12818104 & 12796751 & -21353 \\
\hline Немецкий & 1005961 & 1624079 & +618118 \\
\hline Французский & 306310 & 498283 & +191973 \\
\hline Испанский & 22806 & 46014 & +23208 \\
\hline Китайский & 19280 & 27468 & +8188 \\
\hline Итальянский & 3481 & 13304 & +9823 \\
\hline Арабский & 1905 & 823 & -1082 \\
\hline Другие & 20179 & 21751 & +1572 \\
\hline
\end{tabular}

* Составлено по: Образование в России - 2017. Статистический бюллетень.

М.: Моск. технолог. ун-т, 2017. С. 105-106.

** Данные мониторинга изучения иностранных языков в общеобразовательных организациях России, проводившихся по итогам 2018/2019 учебного года по линии Министерства просвещения РФ.

языку - 42,1\%, по французскому языку - учреждениями суглубленным изучением 39,3\%, по испанскому - 45,5\%, по китай- французского языка). В их числе гимназии скому языку - 29,2\%. Тех, кто смог набрать № 39 и № 110 в Екатеринбурге, гимназия 100 баллов по ЕГЭ по иностранным язы- № 53 в Нижнем Новгороде, лицей № 45 в кам, было в 2019 г. мало (15 человек - по Ростове-на-Дону, школа № 162 и гимназия английскому, 3 - по немецкому, 2 - по ан- № 16 в Новосибирске, школа № 22 в Перми, глийскому и 1 - по китайскому).

гимназия № 3 и Академия Наяновой в Са-

В настоящее время в России насчитыва- маре, Образовательный центр «Школа» в ется также 23 билингвальных образователь- Тольятти, гимназия № 30 в Туле, школа № 20 ных учреждения (школы, гимназии, лицеи, в Волгограде, лицей Никитина в Воронеже, образовательные центры), в которых ряд Международная школа имени А.И. Герцена, профильных предметов преподается на школа № 4 имени Жака-Ива Кусто и школа французском языке (все они являются спе- № 171 в Санкт-Петербурге, а также шесть циализированными общеобразовательными московских школ (№№ 1231, 1251, 1265, 
Tableau 4 - Étude des langues étrangères en tant que première et deuxième (ainsi que troisième et autres) en 2015-2016 dans les écoles, collèges et lycées de Russie

\begin{tabular}{|l|r|r|r|c|}
\hline \multicolumn{1}{|c|}{ Langues } & $\begin{array}{c}\text { Total, en nb de } \\
\text { pers. }\end{array}$ & $\begin{array}{c}\text { Dont en première } \\
\text { langue }\end{array}$ & $\begin{array}{c}\text { Dont en 2e et 3e } \\
\text { langue }\end{array}$ & $\begin{array}{c}\text { Part des 2e et 3e } \\
\text { langues, en \% }\end{array}$ \\
\hline Anglais & 11381929 & 11222124 & 159805 & $1,4 \%$ \\
\hline Allemand & 1004990 & 811829 & 193161 & $19,2 \%$ \\
\hline Français & 275047 & 143917 & 131130 & $47,7 \%$ \\
\hline Espagnol & 19473 & 8108 & 11365 & $58,4 \%$ \\
\hline Chinois & 16181 & 4661 & 111520 & $71,2 \%$ \\
\hline Arabe & 3932 & 3069 & 863 & $21,9 \%$ \\
\hline Italien & 2549 & 638 & 1911 & $75,0 \%$ \\
\hline Autres & 17102 & 3920 & 13182 & $77,1 \%$ \\
\hline
\end{tabular}

Tableau 5 - Nombre d'élèves étudiant des langues étrangères en tant que matière dans les écoles, collèges et lycées de Russie en 2016-2017 et 2018-2019

\begin{tabular}{|l|r|r|c|}
\hline $\begin{array}{c}\text { Langues/années } \\
\text { scolaires }\end{array}$ & 2016-2017* & $\mathbf{2 0 1 8 - 2 0 1 9}$ & $\begin{array}{c}\text { Variations pour les années } \\
\mathbf{2 0 1 6 / 2 0 1 7 - 2 0 1 8 / 2 0 1 9}\end{array}$ \\
\hline Anglais & 12818104 & 12796751 & -21353 \\
\hline Allemand & 1005961 & 1624079 & +618118 \\
\hline Français & 306310 & 498283 & +191973 \\
\hline Espagnol & 22806 & 46014 & +23208 \\
\hline Chinois & 19280 & 27468 & +8188 \\
\hline Italien & 3481 & 13304 & +9823 \\
\hline Arabe & 1905 & 823 & -1082 \\
\hline Autres & 20179 & 21751 & +1572 \\
\hline
\end{tabular}

* Établi d'après : L'enseignement en Russie, 2017, Bulletin statistique, Moscou, Université des technologies de Moscou, 2017, p. 105-106.

** Données de l'enquête sur l'étude des langues étrangères dans les établissements d'enseignement général en Russie menée à l'issue de l'année scolaire 2018-2019 à l'initiative du ministère de l'Instruction publique de la Fédération de Russie.

à Ekaterinbourg, le collège $n^{\circ} 53$ à Nijni Novgorod, le lycée $n^{\circ} 45$ à Rostov-surle-Don, l'école $n^{\circ} 162$ et le collège $n^{\circ} 16$ à Novossibirsk, l'école $n^{\circ} 22$ à Perm, le collège $n^{\circ} 3$ et l'Académie Naïanova à Samara, le Centre d'enseignement «Chkola » à Togliatti, le collège $n^{\circ} 30$ à Toula, l'école $n^{\circ} 20$ à Volgograd, le lycée Nikitine à Voronej, l'École internationale Herzen, l'école $n^{\circ} 4$ Jean-Jacques Cousteau et l'école $n^{\circ} 171$ à Saint-Pétersbourg, ainsi que six écoles à Moscou ( $n^{\circ} 1231$, $1251,1265,1286,1501$ et 1709). Leurs programmes d'enseignement du français ont le statut de sections bilingues de l'Institut français en Russie ${ }^{6}$ qui organise pour les enseignants des établissements cités des séminaires de formation en Russie, des programmes de bourse en France, et assure un accès à différentes ressources d'informations pédagogiques ; quant aux élèves, ils peuvent entrer dans des établissements universitaires en France sans passer l'examen de français d'entrée (en cas de réussite à l'examen final un certificat de français est délivré par l'Ambassade de France en Russie) et pendant leur formation les élèves ont la 

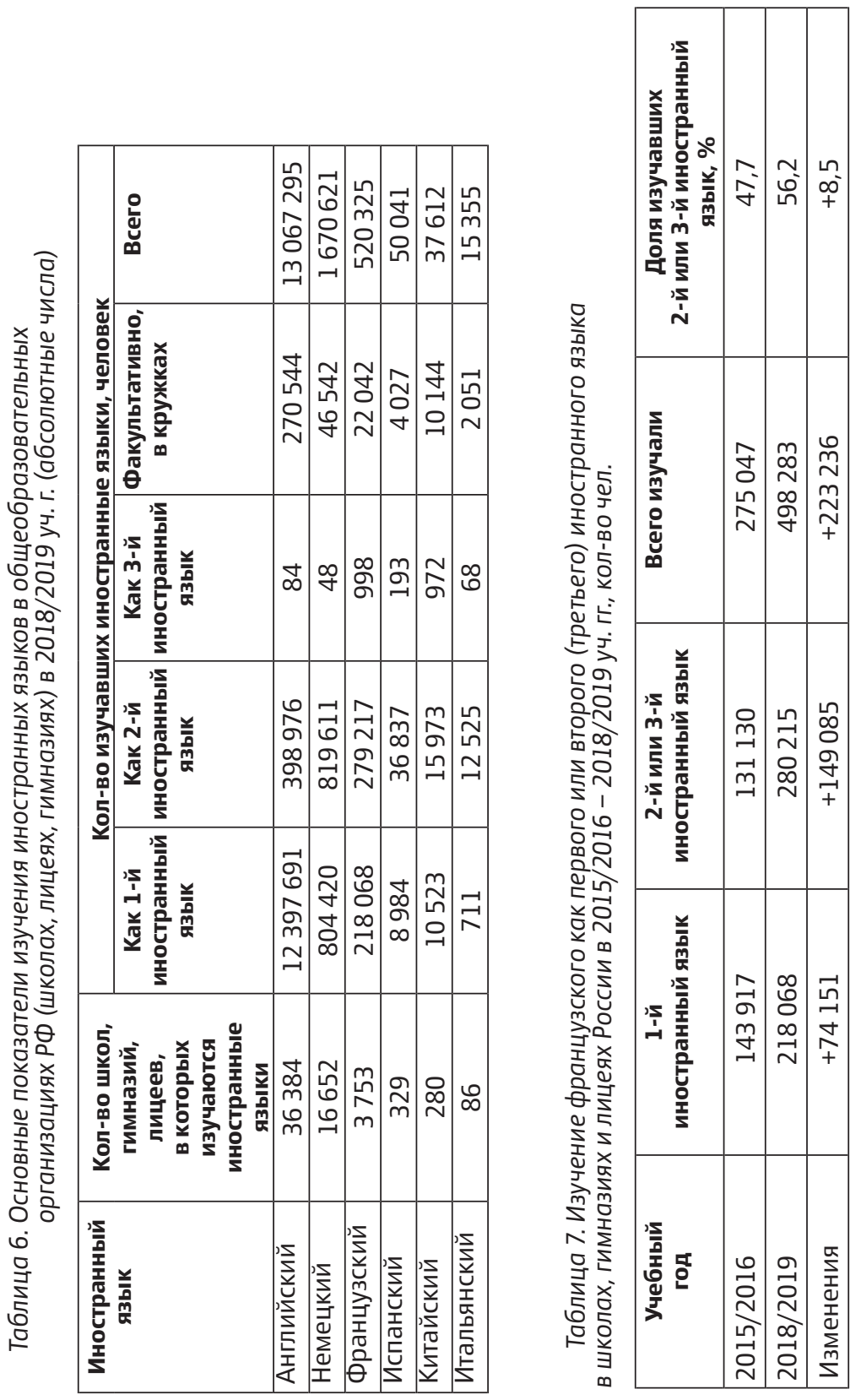


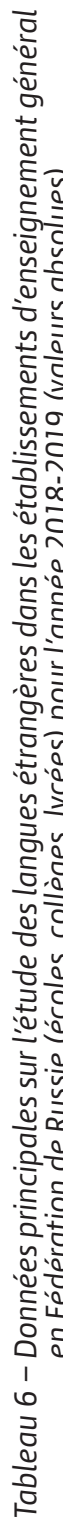

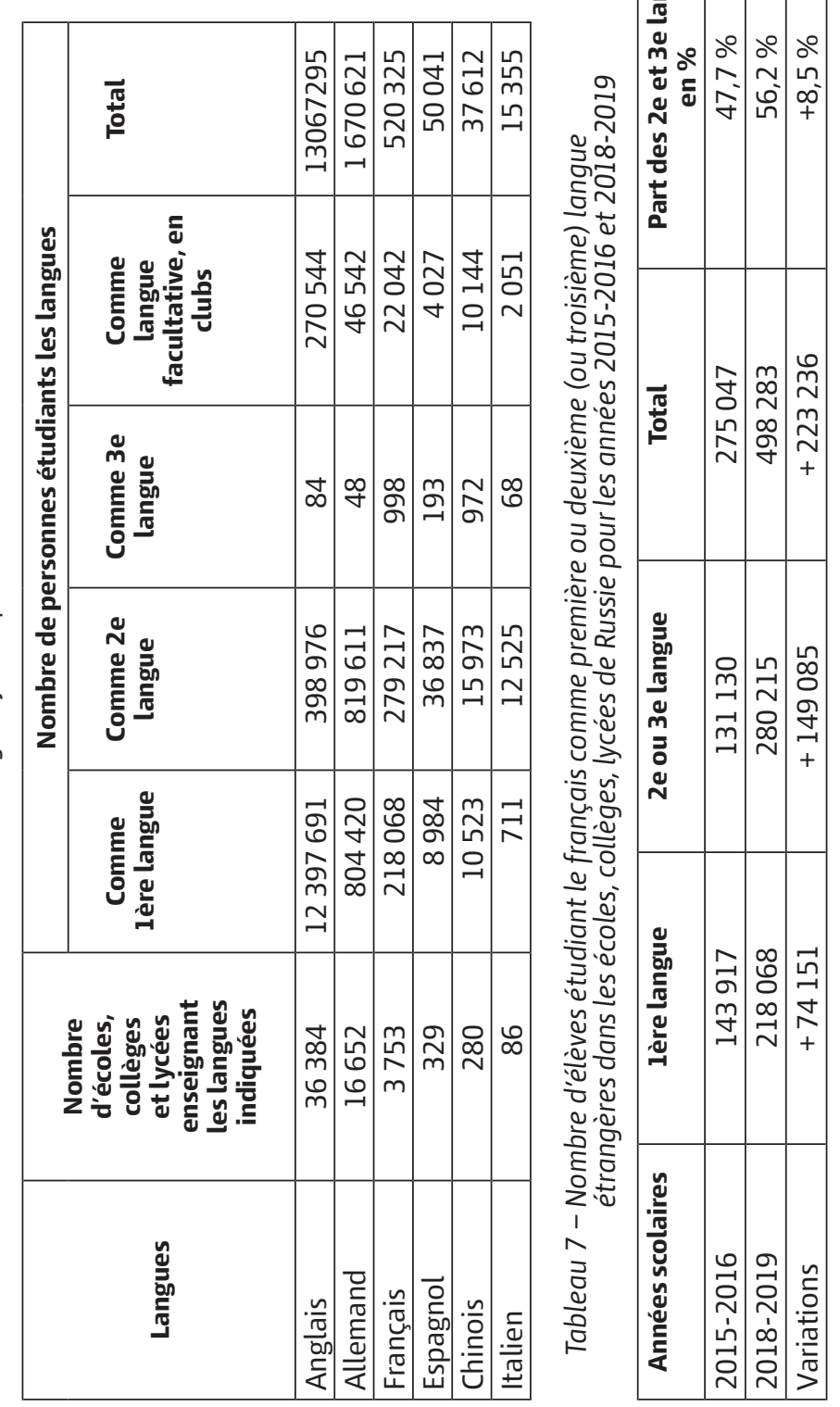




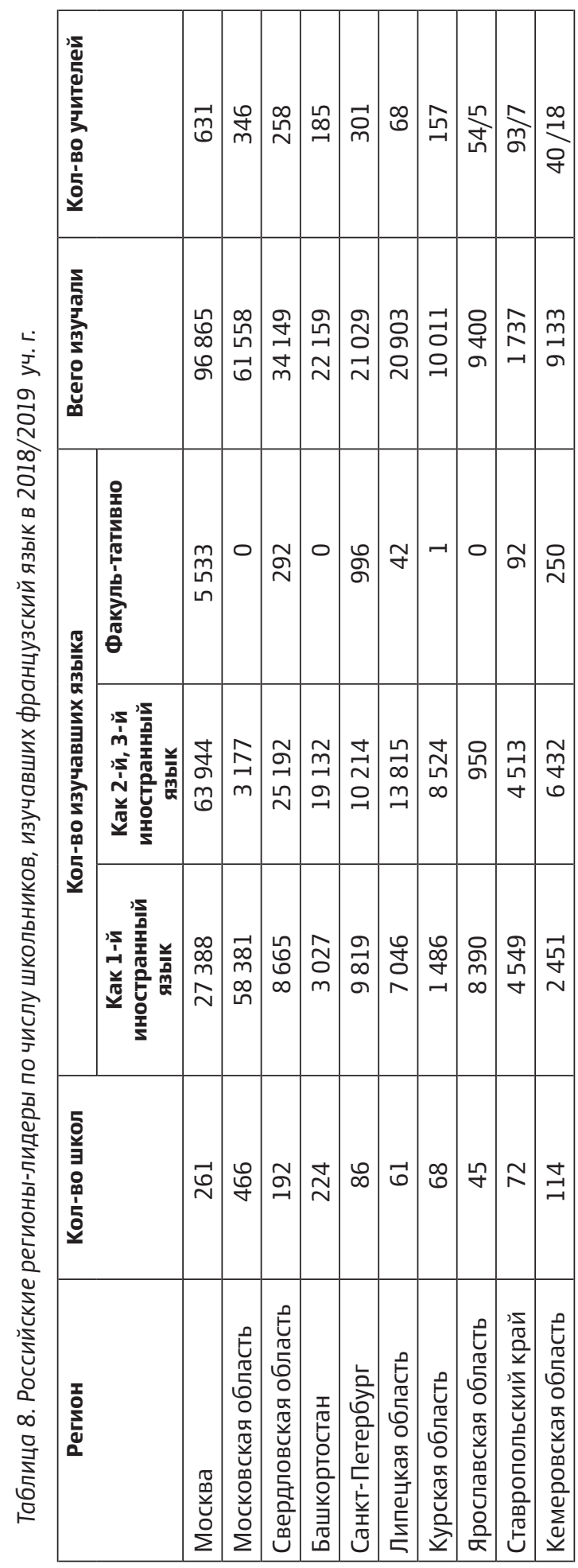

1286, 1501 и 1709). Их программы обучения французскому языку имеют статус двуязычных отделений Французского института в России ${ }^{6}$, который организует для учителей вышеперечисленных учебных заведений образовательные семинары в России, стипендиальные программы во Франции, а также обеспечивает доступ к различным педагогическим ресурсам. Ученики русскофранцузских двуязычных отделений могут поступить во французские университеты без сдачи во Франции экзамена по французскому языку (при успешном окончании отделения выпускникам выдается сертификат Посольства Франции), а в процессе обучения - выезжать во Францию на языковые стажировки. Кроме того, полностью на французском языке и по французским образовательным программам ведется обучение во Французском лицее имени А. Дюма в Москве и Французской школе в Санкт-Петербурге. В этих учебных заведениях учатся дети как французских, так и российских граждан. Контингент учащихся довольно значителен (например, во Французском лицее имени Дюма - более 1300 человек, включая воспитанников детского сада при лицее).

Важную роль в изучении французского языка в системе среднего образования играют Всероссийские школьные олимпиады по французскому языку (первая состоялась в 2002 г.), в которых принимают участие тысячи школьников. Победителей и призеров, которые получают определенные льготы при поступлении в профильный вуз, а также денежное вознаграждение, - более 100.

В связи с увеличением общего количества изучающих французский язык в школах, гимназиях и лицеях несколько выросло и число школьных учителей французского языка: если в 2015/2016 учебном году их насчитывалось 3711 человек, то в 2018/2019 году - 4 604, из них 4067 человек были штатными преподавателями, а 537 - совместителями. При этом нагрузка учителей французского языка возросла: 


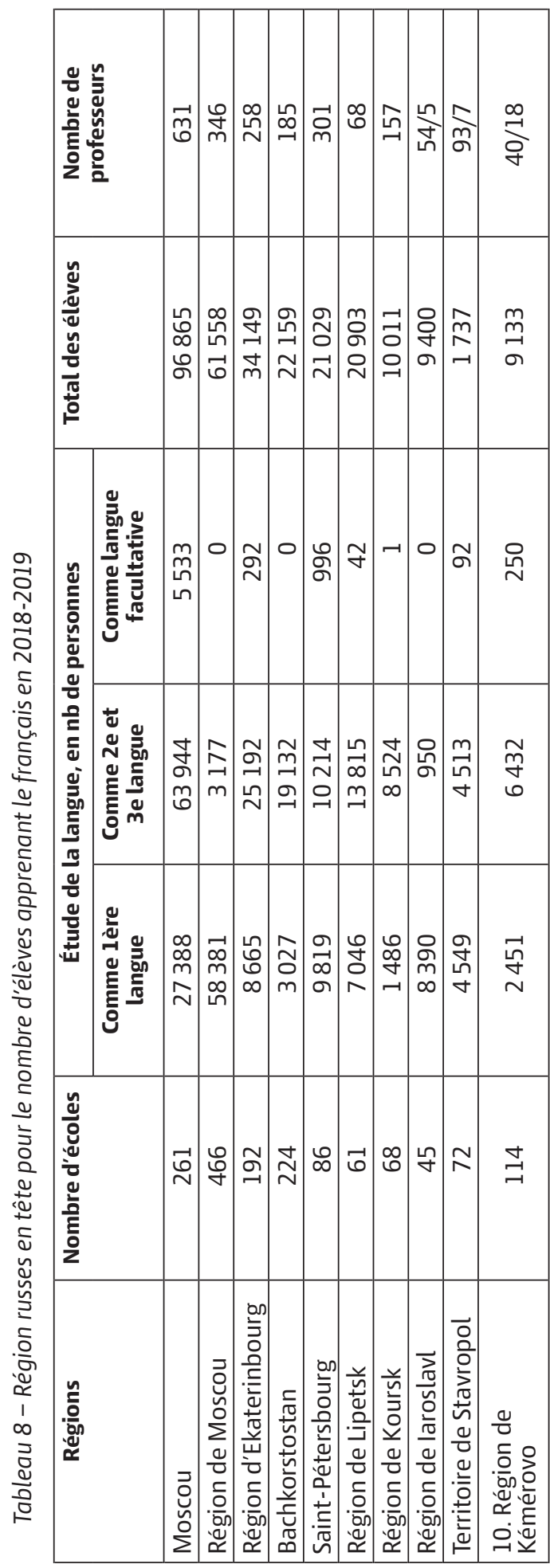

possibilité de suivre des stages en France. En outre, le lycée Alexandre Dumas à Moscou et l'école française à Saint-Pétersbourg fournissent un enseignement complètement dispensé en français et selon les programmes français. Dans ces établissements les écoliers sont citoyens aussi bien français que russes, ils sont assez nombreux : plus de 1300 au lycée Alexandre Dumas, y compris en classes de l'école maternelle.

L'organisation des olympiades scolaires de français dans toute la Russie, qui se sont tenues pour la première fois en 2002 , joue un rôle important dans le soutien apporté à l'étude du français dans le système de l'enseignement secondaire. Ils sont des milliers d'écoliers à y participer, dont plus de 100 sont sélectionnés, gagnant alors des avantages précis pour entrer dans une université spécialisée, ainsi qu'une récompense financière.

Compte tenu de l'augmentation du nombre total d'écoliers apprenant le français dans les écoles, collèges et lycées, celui des professeurs de français en milieu scolaire a aussi augmenté : s'ils étaient 3711 en 2015-2016, ils étaient 4604 en 2018-2019, dont 4067 professeurs titulaires et 537 en temps partagé. La charge des professeurs de français a aussi augmenté: elle était d'un enseignant pour 77 élèves en 2015-2016 (dans le cadre des programmes, hors cours facultatifs) contre 108 élèves en 2018-2019 (hors cours facultatifs).

Les données existantes sur l'âge des professeurs de français pour les années scolaires entre 2011-2012 et 2015-2016 témoignent du problème du vieillissement du personnel enseignant de cette matière, surtout dans les écoles en milieu rural (voir tableaux 12 et 13). On peut aussi noter une prépondérance des femmes parmi les enseignants (le français est enseigné à $98,2 \%$ par des femmes).

Dans le système de l'enseignement professionnel secondaire le nombre de ceux qui étudiaient le français en 2018-2019 était de 8800 seulement (dans 173 établissements), ce qui est nettement inférieur au nombre de l'année 2006-2007 quand ces établissements 


\section{Английскийязык $\longrightarrow$-Немецкий язык $\rightarrow-$ Французскийязык}

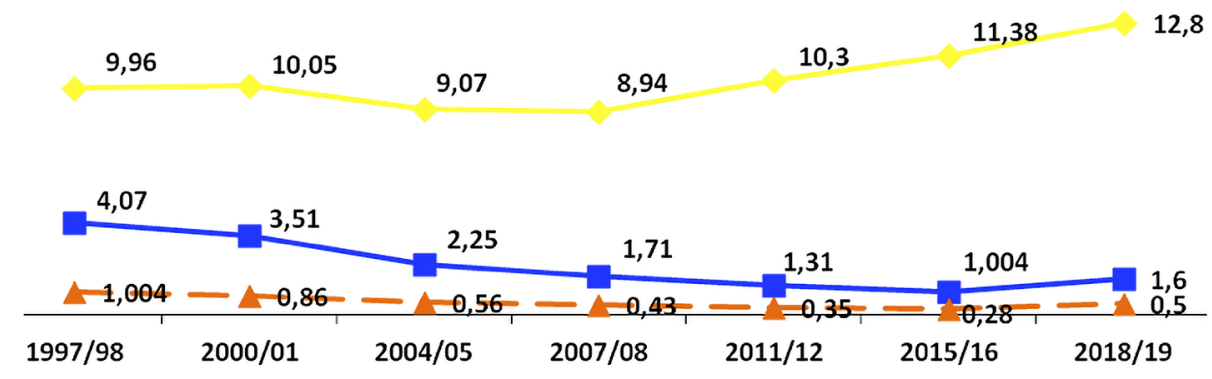

Рисунок 1. Количество изучавших английский, немецкий и французский языки в средних общеобразовательных организациях

(начальных, основных и средних школах, гимназиях и лицеях)

Российской Федерации в 1997/1998 -2018/2019 уч. гг., млн человек

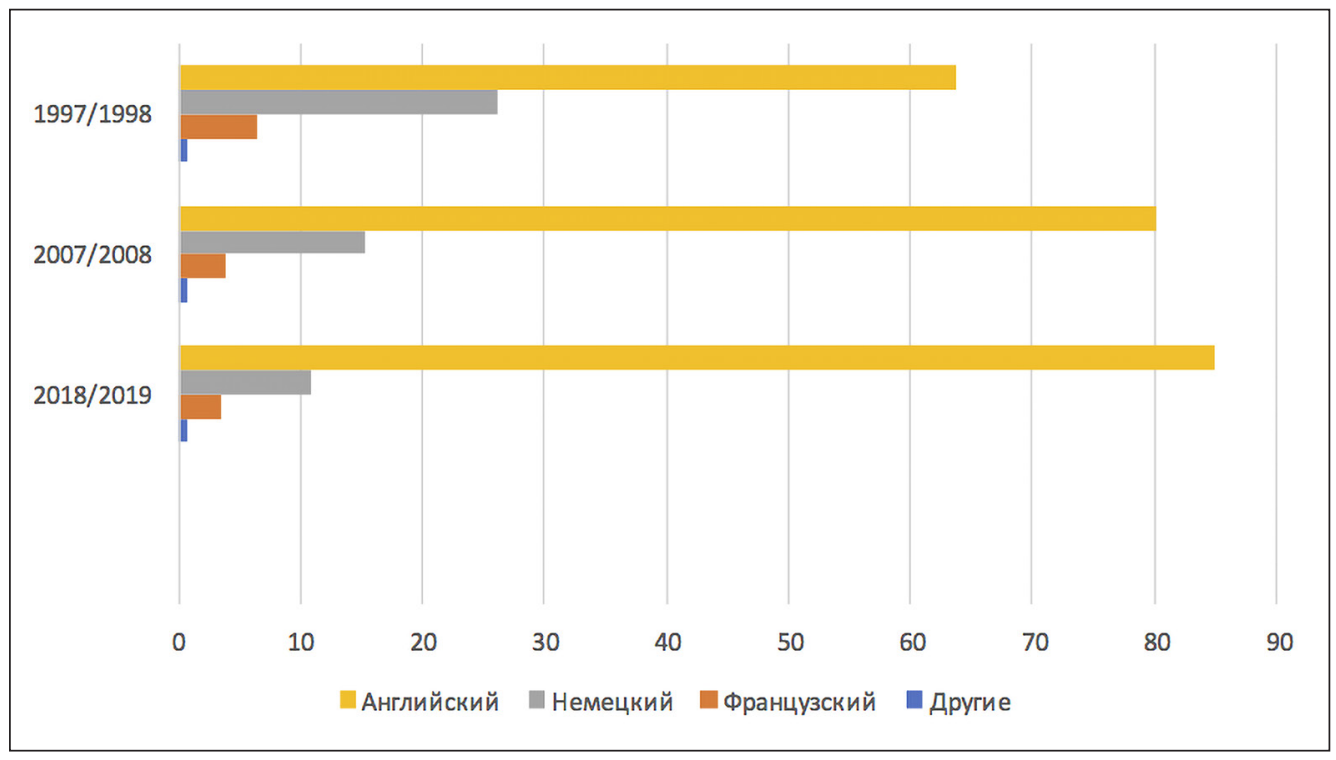

Рисунок 2. Доля российских школьников, изучавших английский, немецкий, французский и другие иностранные языки в 1997/1998, 2007/2008 и 2018/2019 уч. гг., \% 


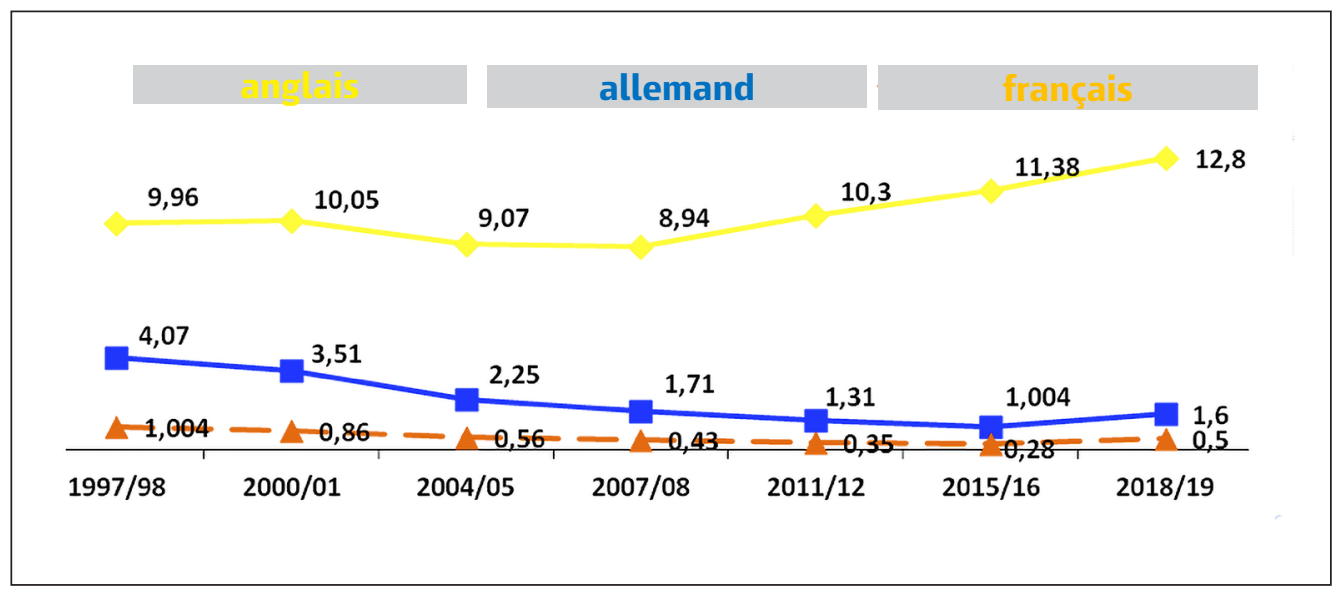

Schéma 1

Nombre d'élèves apprenant l'anglais, l'allemand et le français dans les établissements d'enseignement général du secondaire (écoles primaires, principales et secondaires, collèges, lycées) de la Fédération de Russie dans la période allant de 1997-1998 à 2018-2019, en millions

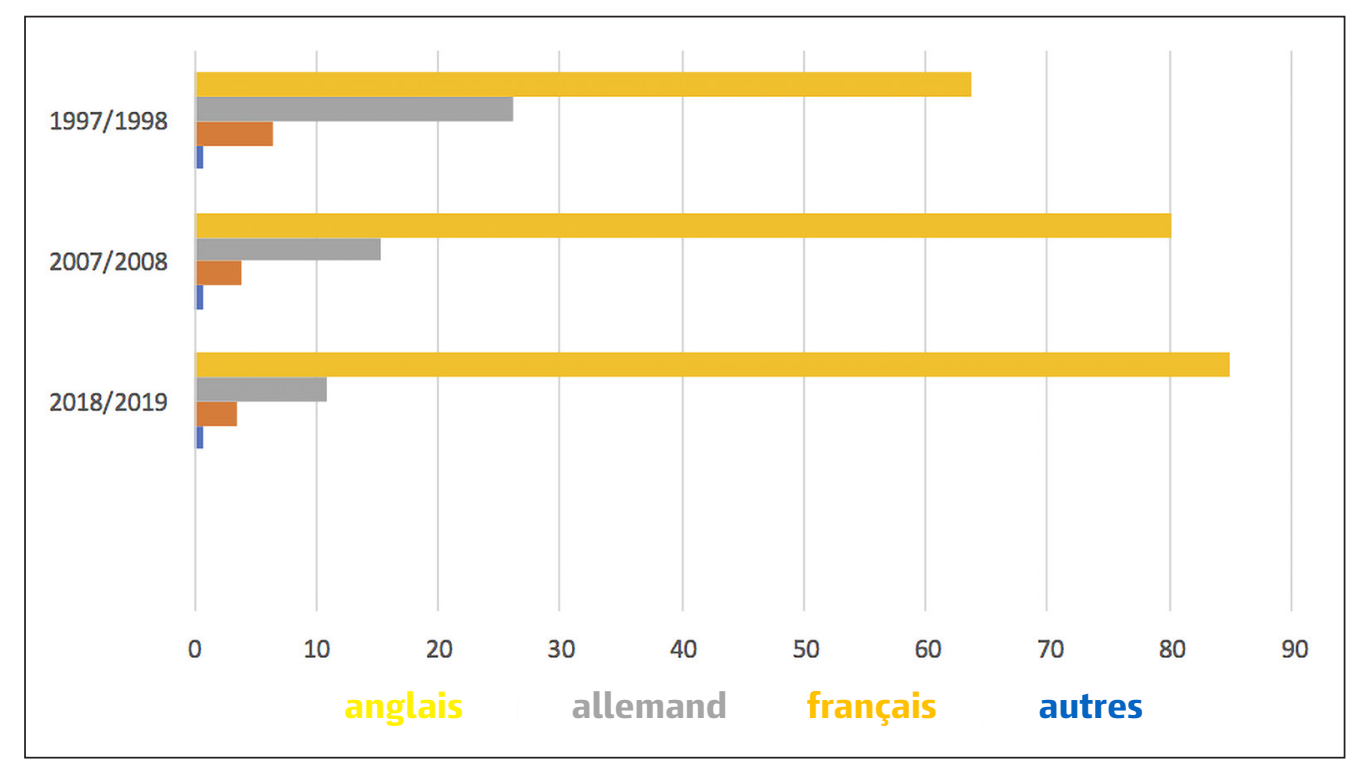

Schéma 2

Part des écoliers russes étudiant l'anglais, l'allemand, le français et d'autres langues étrangères en 1997-1998, 2007-2008 et 2018-2019, en \% 
Таблица 9. Число учащихся различных классов школ, гимназий, лицеев Российской Федерации, изучавших французский язык углубленно в 2016/2017-2018/2019 уч. гг

\begin{tabular}{|l|c|c|c|c|}
\hline \multirow{2}{*}{\multicolumn{1}{|c|}{ Учебный год }} & \multicolumn{3}{|c|}{ Классы } & \multirow{2}{*}{ Всего } \\
\cline { 2 - 3 } & $\mathbf{1 - 4}$ & $\mathbf{5 - 9}$ & $\mathbf{1 0 - 1 1 ( 1 2 )}$ & \\
\hline $2016 / 2017$ & 9581 & 26631 & 4936 & 41148 \\
\hline $2017 / 2018$ & 8180 & 22756 & 4268 & 35204 \\
\hline $2018 / 2019$ & 7938 & 22643 & 4533 & 35114 \\
\hline $\begin{array}{l}\text { Изменения, } \\
\text { 2016/2017-2018/2019 }\end{array}$ & -1643 & -3988 & -403 & -6034 \\
\hline
\end{tabular}

* Для сравнения: английский углубленно учили в 2018/2019 уч. г. 536,5 тыс. учащихся, немецкий - 50,4 тыс.

Таблица 10. Число участников единых государственных экзаменов по иностранным языкам в России в 2012-2019 гг.

\begin{tabular}{|c|c|c|c|c|c|}
\hline \multirow{2}{*}{ Год } & \multicolumn{5}{|c|}{ Язык } \\
\cline { 2 - 6 } & Английский & Немецкий & Французский & Испанский & Китайский* \\
\hline 2012 & 71825 & 2970 & 1621 & 256 & - \\
\hline 2013 & 67500 & 2392 & 1299 & 174 & - \\
\hline 2014 & 69382 & 2428 & 1355 & 165 & - \\
\hline 2015 & 64000 & 1997 & 1000 & 170 & - \\
\hline 2016 & 64050 & 1980 & 1273 & 204 & - \\
\hline 2017 & 64422 & 1769 & 1123 & 231 & - \\
\hline 2018 & 72500 & 1438 & 927 & 134 & 75 \\
\hline 2019 & 74282 & 1253 & 800 & 132 & - \\
\hline
\end{tabular}

* Заявки на сдачу ЕГЭ по китайскому языку подали в 2019 г. 289 чел., но в установленные сроки смогли сдать всего 75 чел.

Таблица 11. Средние тестовые баллы ЕГЭ по иностранным языкам в России в 2014-2019 гг.

\begin{tabular}{|c|c|c|c|c|c|}
\hline \multirow{2}{*}{ Год } & \multicolumn{5}{|c|}{ Язык } \\
\cline { 2 - 6 } & Английский & Немецкий & Французский & Испанский & Китайский \\
\hline 2014 & 61,6 & 54,6 & 69,6 & 72,0 & - \\
\hline 2015 & 64,6 & 61,7 & 73,1 & 76,7 & - \\
\hline 2016 & 69,8 & 66,8 & 73,6 & 74,6 & - \\
\hline 2017 & 70,1 & 63,7 & 75,9 & 68,3 & - \\
\hline 2018 & 69,1 & 68,8 & 76,9 & 78,8 & - \\
\hline 2019 & 73,8 & 72,4 & 73,1 & 72,2 & 62,5 \\
\hline
\end{tabular}


Tableau 9 - Nombre d'élèves de différentes classes d'école, collège et lycée en Fédération de Russie étudiant le français de manière poussée en 2016-2017 - 2018-2019

\begin{tabular}{|l|c|c|c|c|}
\hline \multirow{2}{*}{ Année scolaires } & \multicolumn{3}{|c|}{ Classes } & \multirow{2}{*}{ Total } \\
\cline { 2 - 4 } & $\mathbf{1 - 4}$ & $\mathbf{5 - 9}$ & $\mathbf{1 0 - 1 1 ( 1 2 )}$ & \\
\hline $2016-2017$ & 9581 & 26631 & 4936 & 41148 \\
\hline $2017-2018$ & 8180 & 22756 & 4268 & 35204 \\
\hline $2018-2019$ & 7938 & 22643 & 4533 & 35114 \\
\hline $\begin{array}{l}\text { Variations pour les années } \\
\text { 2016/2017-2018/2019 }\end{array}$ & -1643 & -3988 & -403 & -6034 \\
\hline
\end{tabular}

*À titre de comparaison : 536500 écoliers étudiaient l'anglais de manière approfondie en 2018-2019, ils étaient 50400 pour l'allemand.

Tableau 10 - Nombre d'élèves passant les épreuves de langue étrangère à l'examen de fin de scolarité en Russie pour les années 2012-2019

\begin{tabular}{|c|c|c|c|c|c|}
\hline Années & Anglais & Allemand & Français & Espagnol & Chinois* \\
\hline 2012 & 71825 & 2970 & 1621 & 256 & - \\
\hline 2013 & 67500 & 2392 & 1299 & 174 & - \\
\hline 2014 & 69382 & 2428 & 1355 & 165 & - \\
\hline 2015 & 64000 & 1997 & 1000 & 170 & - \\
\hline 2016 & 64050 & 1980 & 1273 & 204 & - \\
\hline 2017 & 64422 & 1769 & 1123 & 231 & - \\
\hline 2018 & 72500 & 1438 & 927 & 134 & - \\
\hline 2019 & 74282 & 1253 & 800 & 132 & 75 \\
\hline
\end{tabular}

* 289 élèves étaient inscrits en 2019 à l'épreuve de chinois à l'examen de fin de scolarité (EGE), mais seuls 75 ont pu les passer dans les délais prévus.

Tableau 11 - Moyenne des notes aux épreuves de langues étrangères à l'examen de fin de scolarité (EGE) en Russie pour les années 2014-2019

\begin{tabular}{|c|r|r|r|r|r|}
\hline \multirow{2}{*}{ Années } & \multicolumn{7}{|c|}{ Langues } \\
\cline { 2 - 6 } & \multicolumn{1}{|c|}{ Anglais } & \multicolumn{1}{c|}{ Allemand } & Français & \multicolumn{1}{c|}{ Espagnol } & Chinois \\
\hline 2014 & 61,6 & 54,6 & 69,6 & 72,0 & - \\
\hline 2015 & 64,6 & 61,7 & 73,1 & 76,7 & - \\
\hline 2016 & 69,8 & 66,8 & 73,6 & 74,6 & - \\
\hline 2017 & 70,1 & 63,7 & 75,9 & 68,3 & 62,5 \\
\hline 2018 & 69,1 & 68,8 & 76,9 & 78,8 & 72,2 \\
\hline 2019 & 73,8 & 72,4 & 73,1 & & \\
\hline
\end{tabular}


если в 2015/2016 году на одного учителя приходилось 77 учеников (в рамках учебных программ, без учета факультативных занятий), то в 2018/2019 году - 108 учеников (также без учета факультативов).

Вместе с тем имеющиеся данные о возрастном составе школьных учителей французского языка за 2011/2012 - 2015/2016 учебные годы свидетельствуют о проблеме старения педагогических кадров по данной специализации, особенно в сельских школах (см. табл. 12 и 13). Можно также отметить и чрезмерную феминизацию учительского состава (98,2\% преподавателей французского языка - женщины).

В системе среднего профессионального образования количество изучавших французский язык в 2018/2019 учебном году составляло всего 8,8 тыс. человек в 173 организациях среднего профессионального образования (СПО), что значительно меньше, чем в 2006/2007 учебном году, когда французский изучали в 315 организациях начального профессионального образования (НПО) и в 365 организациях СПО в общей сложности 103,5 тыс. человек (см. табл. 14)7. Больше всего изучавших французский язык в организациях СПО в 2018/2019 учебном году отмечалось в Крыму и Московской области (см. табл. 15).

В системе среднего профессионального образования французский язык учат преимущественно как первый иностранный (см. табл. 16).

Французский язык по количеству студентов, которые его изучают (в т.ч. факультативно) в образовательных организациях, реализующих программы СПО, также занимает стабильно третье место после английского (изучают 1,7 млн чел.) и немецкого (146,4 тыс. чел.).

В системе высшего образования Российской Федерации французский язык в 2006/2007 г., согласно результатам мониторинга, проводившегося Центром социологических исследований Минобрнауки России, изучали в целом около 135 тыс. студентов, в том числе 85 тыс. обучались по очной форме (включая несколько тысяч человек, изучавших французский факультативно), около 50 тыс. обучались по вечерней/заочной форме, а также в экстернате. Из них 70,9\% (95,7 тыс. чел.) изучали французский как филологическую или переводческую специальность и первый иностранный, 23,5\% (37,1 тыс. чел.) - как второй иностранный, 5,6\% (7,6 тыс. чел. как факультатив. Французский как иностранный студенты изучали в основном на первом и втором курсах. Общее количество вузов, в которых преподавался французский язык, составляло в 2006/2007 учебном году около 400 (это были прежде всего вузы Рособразования 8 , лингвистические университеты и языковые институты), причем 88 из них являлись партнерскими вузами французских университетов, оказывавших российским партнерам поддержку в изучении французского языка и литературы, в том числе за счет языковых стажировок во Франции российских студентов, стажеров, аспирантов. Только за 2006/2007 учебный год французская сторона поставила в 20 российских университетов учебную литературу, а 1240 российских преподавателей французского языка прошли курсы повышения квалификации в России и во Франции. Наибольшее количество российских вузов, сотрудничавших с французскими университетами по межвузовским договорам, имелось в Москве, Санкт-Петербурге, а также во Владивостоке (11 вузов).

Согласно данным вышеуказанного мониторинга, среди вузов Рособразования наибольшее количество студентов и аспирантов, изучавших в 2006/2007 учебном году французский язык, отмечалось в Московском государственном лингвистическом университете (см. табл. 17).

Помимо Москвы и Санкт-Петербурга (суммарно свыше 50 тыс. студентов и аспирантов) выделялся еще ряд регионов со значительным количеством обучавшихся французскому языку как первому или 
étaient au nombre de 315 pour l'enseignement professionnel initial et 365 pour l'enseignement professionnel secondaire pour un total de 103500 élèves (voir tableau 14)7.

Le plus grand nombre d'élèves étudiants le français dans l'enseignement professionnel secondaire pour l'année scolaire 2018-2019 était enregistré en Crimée et dans la région de Moscou (voir tableau 15).

Dans le système d'enseignement professionnel secondaire le français est majoritairement étudié comme première langue étrangère (voir tableau 16).

En nombre d'élèves étudiant (y compris comme langue facultative) dans les établissements d'enseignement professionnel secondaire le français occupe régulièrement la troisième place après l'anglais (étudié par 1,7 millions d'élèves) et l'allemand (146 000 élèves).

Au sein du système de l'enseignement supérieur en Fédération de Russie le français pour l'année 2006-2007, d'après les résultats d'une enquête menée par le Centre d'études sociologiques du ministère russe de l'Enseignement, était au total étudié par environ 135000 étudiants, dont 85000 en direct (dont plusieurs milliers comme langue facultative) et environ 50000 en cours du soir à distance, ainsi qu'en externe. Parmi eux 70,9\% (95 700) étudiaient le français comme spécialité linguiste ou traduction/interprétation et première langue, 23,5\% (37 100 étudiants) comme deuxième langue, 5,6\% (7 600 étudiants) comme langue facultative. Le français comme langue étrangère était généralement étudié en lère et 2e année d'université. Le nombre total d'établissements proposant des cours de français était pour l'année 2006-2007 d'environ 400 (surtout des établissements relevant de l'Agence fédérale pour l'enseignement, des universités et des instituts de langues étrangères $\left.{ }^{8}\right)$, et 88 d'entre eux étaient partenaires d'universités françaises qui assuraient un soutien dans l'étude de la langue et de la littérature françaises, notamment au moyen de stages de langue pour les étudiants de licence ou de master. Pour la seule année 2006-2007 la partie française a fourni des manuels à 20 universités et 1240 professeurs de français d'universités russes ont suivi des formations en Russie et en France. Le plus grand nombre des universités russes coopérant avec des institutions en France en vertu de convention se trouvait à Moscou, Saint-Pétersbourg et Vladivostok, soit 11 établissements d'enseignement supérieur.

Selon l'enquête citée plus haut, parmi les établissements d'enseignement supérieur de l'Agence fédérale de l'enseignement le plus grand nombre d'étudiants de français pour l'année 2006-2007 se trouvait dans l'Université d'État des langues étrangères de Moscou (voir tableau 17).

En plus de Moscou et de Saint-Pétersbourg dont les universités proposent un enseignement du français (soit au total 50000 étudiants et doctorants), un certain nombre de régions se distinguaient par leur nombre important d'étudiants en français comme première ou deuxième langue étrangère, ou bien facultative : la république de Sakha-Yakoutie (avec 8268 étudiants), la région de Belgorod (5 610), le territoire de Krasnodar (3 234), la république du Tatarstan (2 624).

Le nombre d'enseignants de français dans les établissements d'enseignement supérieur pour l'année 2006-2007 était d'environ 4000 (y compris en temps partagé), et le nombre total de professeurs de français dans les établissements d'enseignement en Russie, tous niveaux confondus, était de 12700. 
Таблица 12. Возрастной состав учителей французского языка городских школ в 2011/2012 и в 2015/2016 уч. гг., \%

\begin{tabular}{|l|c|c|c|c|}
\hline \multirow{2}{*}{ Учебный год } & \multicolumn{4}{|c|}{ Возрастная группа } \\
\cline { 2 - 5 } & Моложе 25 лет & $\mathbf{2 5 - 3 5}$ лет & $\mathbf{3 5 - 5 5}$ лет & Старше 55 лет \\
\hline $2011 / 2012$ & 6,7 & 11,1 & 48,7 & 33,4 \\
\hline $2015 / 2016$ & 5,2 & 14,4 & 39,8 & 40,5 \\
\hline Изменения & $-1,5$ & $+3,3$ & $-8,9$ & $+7,1$ \\
\hline
\end{tabular}

Таблица 13. Возрастной состав учителей французского языка сельских школ в 2011/2012 и в 2015/2016 уч. гг., \%

\begin{tabular}{|l|c|c|c|c|}
\hline \multirow{2}{*}{ Учебный год } & \multicolumn{4}{|c|}{ Возрастная группа } \\
\cline { 2 - 5 } & Моложе 25 лет & $\mathbf{2 5 - 3 5}$ лет & $\mathbf{3 5 - 5 5}$ лет & Старше 55 лет \\
\hline $2011 / 2012$ & 2,5 & 8,8 & 58,7 & 30,0 \\
\hline $2015 / 2016$ & 2,4 & 6,4 & 47,6 & 43,6 \\
\hline Изменения & $-0,1$ & $-2,4$ & $-11,1$ & $+13,6$ \\
\hline
\end{tabular}

Таблица 14. Показатели изучения французского языка в системе начального и среднего профессионального образования России в 2006/2007 и 2018/2019 уч. гг.

\begin{tabular}{|l|l|l|l|}
\hline \multirow{2}{*}{ Показатель } & \multicolumn{2}{c|}{ Учебный год } & \multirow{2}{*}{ Изменения } \\
\cline { 2 - 4 } & \multicolumn{1}{|c|}{$\mathbf{2 0 0 6 / 2 0 0 7}$} & \multicolumn{1}{c|}{$\mathbf{2 0 1 8 / 2 0 1 9}$} & \\
\hline $\begin{array}{l}\text { Кол-во организаций НПО и СПО } \\
\text { с преподаванием французского языка }\end{array}$ & $\begin{array}{l}\text { 315 организаций } \\
\text { НПО и 365 СПО }\end{array}$ & $\begin{array}{l}180 \text { организаций } \\
\text { СПО* }\end{array}$ & -500 \\
\hline Кол-во изучавших французский язык & 103460 & 8840 & -94620 \\
\hline Кол-во преподавателей французского & 2200 & 205 & -1995 \\
\hline
\end{tabular}

* C 2013 г. начальное профессиональное образование включено в систему среднего профессионального образования.

Таблица 15. Российские регионы-лидеры по числу студентов организаций начального и среднего профессионального образования, изучавших французский язык в 2018/2019 уч. г.

\begin{tabular}{|l|c|c|c|}
\hline \multicolumn{1}{|c|}{ Регион } & $\begin{array}{c}\text { Кол-во организаций } \\
\text { Спо с преподаванием } \\
\text { французского языка }\end{array}$ & $\begin{array}{c}\text { Кол-во изучавших } \\
\text { французский язык }\end{array}$ & $\begin{array}{c}\text { Кол-во преподавателей } \\
\text { французского языка }\end{array}$ \\
\hline Республика Крым & 5 & 1341 & 7 \\
\hline Московская область & 9 & 693 & 11 \\
\hline Самарская область & 4 & 607 & 4 \\
\hline Пермский край & 4 & 580 & 11 \\
\hline Орловская область & 11 & 551 & 10 \\
\hline Республика Коми & 7 & 440 & 10 \\
\hline Нижегородская область & 6 & 435 & 6 \\
\hline Республика Татарстан & 3 & 402 & 10 \\
\hline Свердловская область & 6 & 350 & 8 \\
\hline Москва & 8 & 346 & 4 \\
\hline
\end{tabular}


Tableau 12 - Répartition par âge des enseignants de français des écoles en ville dans les années scolaires 2011-2012 et 2015-2016, en \%

\begin{tabular}{|l|c|c|c|c|}
\hline \multirow{2}{*}{$\begin{array}{c}\text { Années } \\
\text { scolaires }\end{array}$} & \multicolumn{4}{|c|}{ Groupes d'âge } \\
\cline { 2 - 5 } & Moins de 25 ans & De 25 à 35 ans & $\mathbf{3 5 - 5 5}$ ans & Plus de 55 ans (retraités) \\
\hline $2011-2012$ & 6,7 & 11,1 & 48,7 & 33,4 \\
\hline $2015-2016$ & 5,2 & 14,4 & 39,8 & 40,5 \\
\hline Variations & $-1,5$ & $+3,3$ & $-8,9$ & $+7,1$ \\
\hline
\end{tabular}

Tableau 13 - Répartition par âge des enseignants de français des écoles en milieu rural dans les années scolaires 2011-2012 et 2015-2016, en \%

\begin{tabular}{|l|c|c|c|c|}
\hline \multirow{2}{*}{$\begin{array}{c}\text { Années } \\
\text { scolaires }\end{array}$} & \multicolumn{4}{|c|}{ Groupes d'âge } \\
\cline { 2 - 5 } & Moins de 25 ans & De 25 à $\mathbf{3 5}$ ans & $\mathbf{3 5 - 5 5}$ ans & Plus de 55 ans (retraités) \\
\hline $2011-2012$ & 2,5 & 8,8 & 58,7 & 30,0 \\
\hline $2015-2016$ & 2,4 & 6,4 & 47,6 & 43,6 \\
\hline Variations & $-0,1$ & $-2,4$ & $-11,1$ & $+13,6$ \\
\hline
\end{tabular}

Tableau 14 - Nombre d'élèves apprenant le français dans les systèmes initial et secondaire d'enseignement professionnel en Russie pour les années 2006-2007 et 2018-2019

\begin{tabular}{|l|c|c|c|}
\hline \multicolumn{1}{|c|}{ Années scolaires } & $\mathbf{2 0 0 6 - 2 0 0 7}$ & $\mathbf{2 0 1 8 - 2 0 1 9}$ & Variations \\
\hline $\begin{array}{c}\text { Nombre d'établissements d'enseignement } \\
\text { professionnel primaire et secondaire avec } \\
\text { enseignement du français }\end{array}$ & $\begin{array}{c}315 \text { en } \\
\text { primaire et 365 } \\
\text { secondaire }\end{array}$ & $\begin{array}{c}180 \text { en } \\
\text { secondaire* }\end{array}$ & -500 \\
\hline Nombre d'élèves en français & 103460 & 8840 & -94620 \\
\hline Nombre d'enseignants de français & 2200 & 205 & -1995 \\
\hline
\end{tabular}

* Depuis 2013 l'enseignement professionnel initial est inclus dans le système d'enseignement secondaire professionnel.

Tableau 15 - Régions de Russie en tête du classement en nombre d'élèves étudiant le français dans le système d'enseignement professionnel itinial et secondaire pour l'année 2018-2019

\begin{tabular}{|l|c|c|c|}
\hline \multicolumn{1}{|c|}{ Régions } & $\begin{array}{c}\text { Nombre d'établissements } \\
\text { d'enseignement professionnel } \\
\text { secondaire avec enseignement } \\
\text { du français }\end{array}$ & $\begin{array}{c}\text { Nombre d'élèves } \\
\text { en français }\end{array}$ & $\begin{array}{c}\text { Nombre d'enseignants } \\
\text { de français }\end{array}$ \\
\hline République de Crimée & 5 & 1341 & 7 \\
\hline Région de Moscou & 9 & 693 & 11 \\
\hline Région de Samara & 4 & 607 & 4 \\
\hline Territoire de Perm & 4 & 580 & 4 \\
\hline Région d'Orel & 11 & 551 & 11 \\
\hline République des Komis & 7 & 440 & 10 \\
\hline Région de Nijni Novgorod & 6 & 435 & 10 \\
\hline République du Tatarstan & 3 & 402 & 6 \\
\hline Région d'Ekaterinbourg & 6 & 350 & 10 \\
\hline Moscou & 8 & 346 & 8 \\
\hline
\end{tabular}



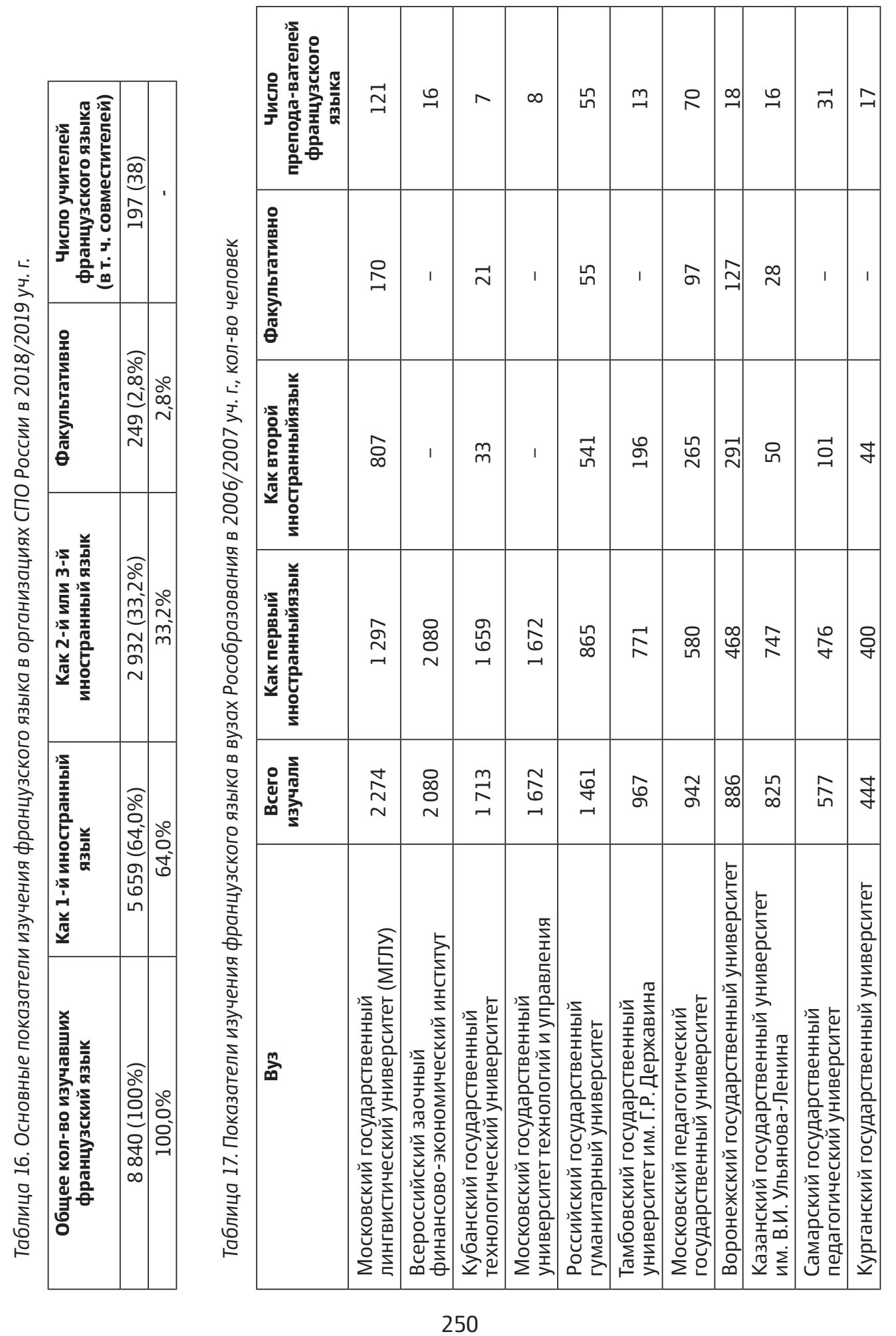

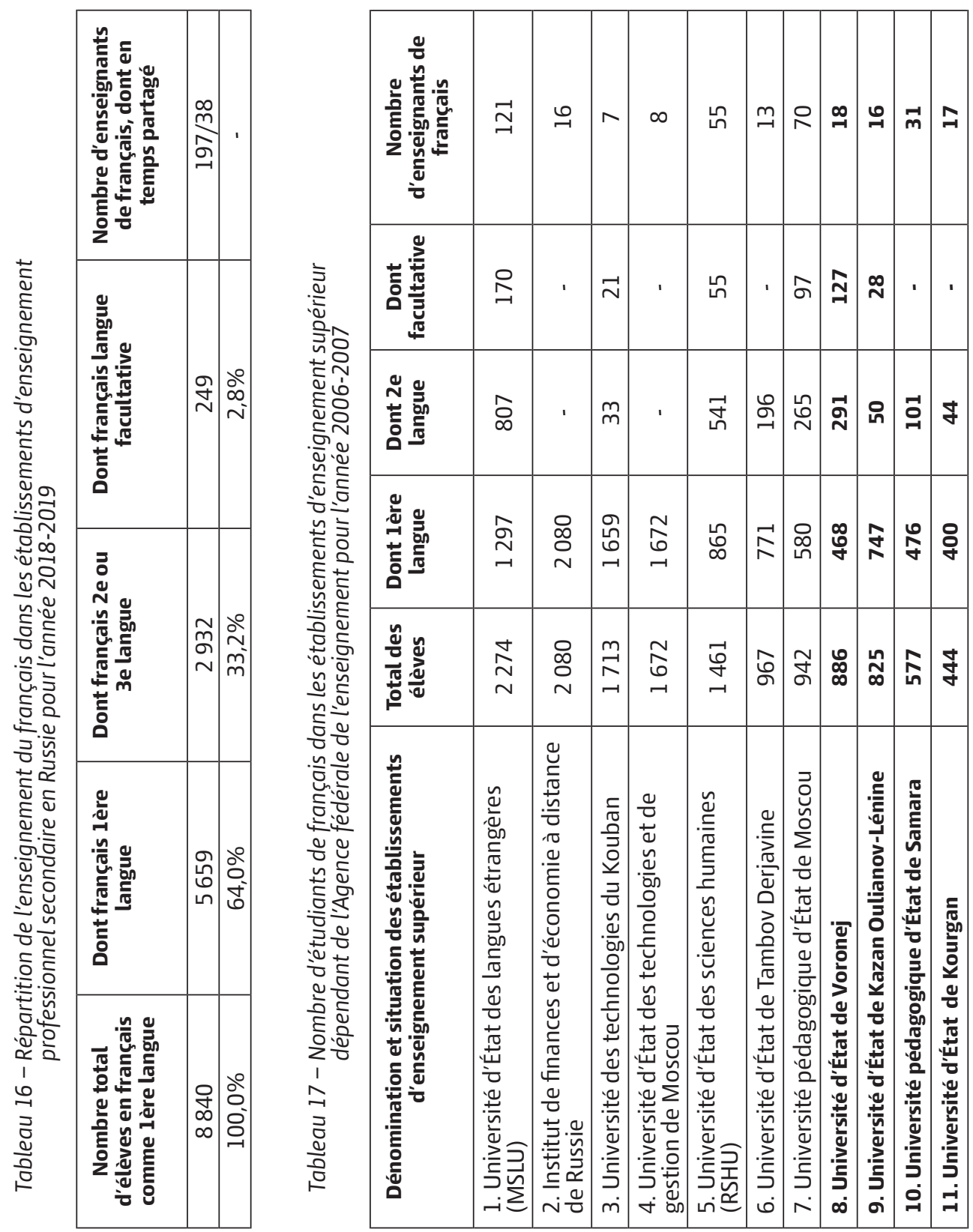
второму иностранному либо факультативно: Республика Саха (Якутия) (8 268 чел.), Белгородская область (5 610 чел.), Краснодарский край (3 234 чел.), Республика Татарстан (2 624 чел.).

Число преподавателей французского языка в российских вузах в 2006/2007 учебном году составляло около 4000 человек (включая совместителей), а общее число учителей и преподавателей французского языка во всех типах российских учебных организаций - 12,7 тыс. человек.

В 2014/2015 учебном году общее количество студентов, изучавших французский язык в российской высшей школе по всем программам (включая вузы МВД, Минобороны, ФСБ, МЧС), составило менее 40 тыс. человек, или около 1\% всех обучавшихся, а количество российских вузов, имевших программы преподавания французского языка, сократилось вдвое (их было около 200). К настоящему времени ситуация, как представляется, существенно не изменилась.

Больше всего студентов, выбравшихдля изучения французский, насчитывалось в 2014/2015 учебном году в Московском государственном лингвистическом университете - 1,6 тыс. человек, из которых более $90 \%$ изучали французский по очной форме. МГлУ на протяжении более 15 лет лидирует и по числу студентов, изучающих французский как лингвистическую специальность (на переводческом факультете обучались 104 человека, остальные учили французский по филологическим программам бакалавриата, специалитета и магистратуры). Одновременно в МГЛУ отмечалась и очень незначительная доля студентов, изучавших французский язык заочно (5,8\%, или 92 человека). Всего в России в 2014/2015 учебном году насчитывалось около 30 вузов (в т.ч. 10 московских), где французский язык изучали более 300 человек (см. табл. 18).

Один из немногих вузов, который смог в последние годы сохранить и даже увеличить в 2017/2018 учебном году контингент изучавших французский язык - Нижегородский государственный лингвистический университет имени Н.А. Добролюбова. В этом университете французский язык изучали 458 человек: 224 - как первый иностранный (в основном как специальность по программам бакалавриата и магистратуры, а также как первый иностранный на нелингвистических специализациях), 181 - как второй иностранный язык (на филологических и нефилологических факультетах) и 43 человека изучали французский по программам ДПо.

В большинстве региональных, а также в целом ряде столичных вузов продолжается его «вымывание» из учебных программ. В качестве примера можно привести Воронежский государственный университет, где в 2006/2007 учебном году количество студентов, изучавших французский язык, составляло около 900 человек, в том числе до 400 человек изучали французский как лингвистическую специальность. Десятилетие спустя (в 2017/2018 уч. г.) контингент освоивших французский язык сократился до 310 человек, в том числе всего 140 изучали французский как лингвистическую специальность (из которых лишь для 80 французский являлся первым языком, в то время как 60 студентов учили французский в качестве второго иностранного языка, первым был английский).

Студентам-первокурсникам, изучавшим в школе французский язык, нередко предлагают после зачисления приступить к освоению английского, с нулевого уровня. Ликвидируются кафедры французского языка, превращаясь в секции объединенных кафедр иностранных или романо-германских языков. Существуют и проблемы с учебной литературой, особенно для студентов инженерно-технических факультетов. Старыми учебниками не позволяют пользоваться Федеральные государственные образовательные стандарты, и поэтому преподаватели нередко вынуждены сами составлять учебно-методические пособия и 
Pour l'année 2014-2015 le nombre total d'étudiants de français dans les grandes écoles tous programmes confondus (y compris les établissements d'enseignement supérieur des ministères de l'Intérieur, de la Défense et des Situations d'urgence, et du Service fédéral de sécurité) était de moins de 40000 , soit $1 \%$ de tous les étudiants, et le nombre d'établissements d'enseignement supérieur proposant des programmes d'enseignement du français a été divisé par deux, contre environ 200 précédemment. À l'heure actuelle, la situation ne semble pas avoir fondamentalement changé.

Le plus grand nombre d'étudiants ayant choisi d'étudier le français a été compté lors de l'année 2014-2015 à l'Université d'État des langues étrangères (MGLU, 1600 étudiants), dont plus de 90\% l'étudiaient en direct. MGLU est depuis plus de 15 ans en tête du classement en nombre d'étudiants de français comme spécialité linguistique (ils étaient 104 à la faculté de traduction et d'interprétation, les autres l'étudiant en licence, spécialité ou master dans la filière linguistique). En même temps MGLU avait une part très peu significative d'étudiants de français à distance (5,8\%, soit 92). Au total en Russie, pour l'année 2014-2015 on dénombrait 30 établissements d'enseignement supérieur (dont 10 à Moscou) comptant plus de 300 étudiants de français (voir tableau 18 ci-dessous).

L'un des rares établissements d'enseignement supérieur à avoir pu conserver et même augmenter en 2017-2018 le nombre d'étudiants de français est l'Université d'État des langues étrangères de Nijni Novgorod Dobrolioubov : 458 étudiants en 2017-2018, dont presque la moitié - 224 - en première langue (principalement comme spécialité en licence et master, ainsi qu'en première langue dans des spécialisations autres que linguistiques), 181 en deuxième langue (dans les facultés linguistiques et non-linguistiques), et 43 dans les programmes de formation professionnelle complémentaire.

Dans la plupart des établissements d'enseignement supérieur régionaux, et même de la capitale, se poursuit le processus de « nettoyage » des programmes universitaires. On peut citer comme exemple l'Université d'État de Voronej où en 2006-2007 le nombre d'étudiants de français était d'environ 900, dont 400 comme spécialité linguistique. Une décennie plus tard (en 2017-2018), le nombre de ceux qui étudient le français est tombé à 310 , dont seulement 140 pour lesquels c'est la spécialité linguistique, et parmi eux seuls 80 l'ont en première langue et 60 en deuxième (la première étant l'anglais).

Les étudiants de première année qui ont étudié le français à l'école se voient souvent proposer d'apprendre l'anglais à partir de zéro après leur intégration à l'université. Les départements de français sont dissous et transformés en sections de départements de langues étrangères ou des langues romanes et germaniques. On constate des problèmes au niveau des manuels, notamment pour les étudiants des facultés d'ingénieurs et techniques. Les normes en matière d'enseignement des institutions fédérales ne permettent pas d'utiliser les anciens manuels et les enseignants se trouvent souvent obligés de composer eux-mêmes des manuels et de les mettre à jour régulièrement (surtout en matière de terminologie).

Le nombre d'enseignants dans les établissements d'enseignement supérieurs a lui-même fortement diminué : ils sont estimés aujourd'hui à 1800 (y compris ceux qui travaillent à temps partagé), dont la moitié sont membres de l'Association des enseignants de français en Russie9. En 2012 l'Association comptait 1200 
Таблица 18. Показатели изучения французского языка в российских вузах в 2014/2015 уч. г.

\begin{tabular}{|c|c|c|c|c|}
\hline \multirow[t]{2}{*}{ Вуз } & \multicolumn{3}{|c|}{$\begin{array}{c}\text { Численность изучавших } \\
\text { французский язык, человек }\end{array}$} & \multirow{2}{*}{\begin{tabular}{|c|} 
Численность \\
преподавателей \\
французского \\
языка, человек
\end{tabular}} \\
\hline & \begin{tabular}{|c} 
Всего \\
изучали
\end{tabular} & $\begin{array}{c}\text { Как } \\
\text { лингвистическую } \\
\text { спец иальность }\end{array}$ & \begin{tabular}{|c|} 
Как \\
иностранный \\
язык
\end{tabular} & \\
\hline $\begin{array}{l}\text { Московский государственный } \\
\text { лингвистический университет* }\end{array}$ & 1582 & 937 & 645 & 89 \\
\hline $\begin{array}{l}\text { Казанский (Приволжский) } \\
\text { федеральный университет }\end{array}$ & 1414 & 770 & 644 & 23 \\
\hline МГУ имени М.В. Ломоносова & 1160 & 320 & 840 & 60 \\
\hline ВШЭ (г. Москва) & 1029 & 173 & 856 & 35 \\
\hline РАНХиГС (г. Москва) & 1010 & 10 & 1000 & 100 \\
\hline $\begin{array}{l}\text { Северо-Восточный федеральный } \\
\text { университет (г. Якутск) }\end{array}$ & 1003 & 88 & 915 & 20 \\
\hline РУДН (г. Москва) & 966 & 414 & 552 & 36 \\
\hline $\begin{array}{l}\text { Московский педагогический } \\
\text { государственный университет }\end{array}$ & 670 & 240 & 430 & 22 \\
\hline $\begin{array}{l}\text { Санкт-Петербургский } \\
\text { государственный экономический } \\
\text { университет }\end{array}$ & 650 & 30 & 620 & 23 \\
\hline СПбгу & 550 & 130 & 220 & 25 \\
\hline $\begin{array}{l}\text { Нижегородский государственный } \\
\text { лингвистический университет имени } \\
\text { Н.А. Добролюбова* }\end{array}$ & 458 & 302 & 156 & 20 \\
\hline МПТУ имени Н.Э. Баумана (г. Москва) & 450 & 0 & 450 & 7 \\
\hline $\begin{array}{l}\text { Пензенский государственный } \\
\text { университет }\end{array}$ & 428 & 220 & 228 & 15 \\
\hline $\begin{array}{l}\text { Московский государственный } \\
\text { строительный университет }\end{array}$ & 400 & 0 & 400 & 5 \\
\hline $\begin{array}{l}\text { Воронежский государственный } \\
\text { университет }\end{array}$ & 395 & 145 & 250 & 15 \\
\hline $\begin{array}{l}\text { Государственный гуманитарно- } \\
\text { технологический университет } \\
\text { (г. Орехово-Зуево) }\end{array}$ & 380 & 300 & 80 & 9 \\
\hline $\begin{array}{l}\text { Курский государственный } \\
\text { университет }\end{array}$ & 368 & 157 & 211 & 17 \\
\hline $\begin{array}{l}\text { Пятигорский государственный } \\
\text { лингвистический университет }\end{array}$ & 362 & 105 & 257 & 25 \\
\hline $\begin{array}{l}\text { Тульский государственный } \\
\text { университет }\end{array}$ & 342 & 65 & 277 & 14 \\
\hline $\begin{array}{l}\text { Южный федеральный университет } \\
\text { (г. Ростов-на-Дону) }\end{array}$ & 327 & 125 & 202 & 16 \\
\hline $\begin{array}{l}\text { Тюменский государственный } \\
\text { университет }\end{array}$ & 318 & 171 & 147 & 20 \\
\hline $\begin{array}{l}\text { Российский государственный } \\
\text { педагогический университет имени } \\
\text { А.И. Герцена (г. Санкт-Петербург) }\end{array}$ & 316 & 116 & 200 & 15 \\
\hline
\end{tabular}

*Данные за 2017/2018 уч. г. 
Tableau 18 - Nombre d'étudiants de français dans les établissements d'enseignement supérieur pour l'année 2014-2015

\begin{tabular}{|c|c|c|c|c|}
\hline $\begin{array}{c}\begin{array}{c}\text { Dénomination et situation des établissements } \\
\text { d'enseignement supérieur }\end{array} \\
\end{array}$ & $\begin{array}{c}\text { Total des } \\
\text { élèves }\end{array}$ & $\begin{array}{c}\text { Dont lère } \\
\text { langue }\end{array}$ & $\begin{array}{l}\text { Dont 2e } \\
\text { langue }\end{array}$ & $\begin{array}{c}\text { Dont } \\
\text { facultative }\end{array}$ \\
\hline $\begin{array}{l}\text { 1. Université d'État des langues étrangères } \\
(\text { MSLU)* }\end{array}$ & 1582 & 937 & 645 & 89 \\
\hline $\begin{array}{l}\text { 2. Université fédérale d'État de Kazan (Bassin de } \\
\text { la Volga) }\end{array}$ & 1414 & 770 & 644 & 23 \\
\hline 3. Université d'État de Moscou Lomonossov & 1160 & 320 & 840 & 60 \\
\hline $\begin{array}{l}\text { 4. École des hautes études en sciences } \\
\text { économiques (Moscou) }\end{array}$ & 1029 & 173 & 856 & 35 \\
\hline $\begin{array}{l}\text { 5. Académie d'économie populaire et de } \\
\text { fonction publique de Russie (Moscou) }\end{array}$ & 1010 & 10 & 1000 & 100 \\
\hline 6. Université fédérale du Nord-est (lakoutsk) & 1003 & 88 & 915 & 20 \\
\hline $\begin{array}{l}\text { 7. Université d'État de l'amitié entre les peuples } \\
\text { (Moscou) }\end{array}$ & 966 & 414 & 552 & 36 \\
\hline 8. Université pédagogique d'État de Moscou & 670 & 240 & 430 & 22 \\
\hline $\begin{array}{l}\text { 9. Université d'État d'économie de Saint- } \\
\text { Pétersbourg }\end{array}$ & 650 & 30 & 620 & 23 \\
\hline 10. Université d'État de Saint-Pétersbourg & 550 & 130 & 220 & 25 \\
\hline $\begin{array}{l}\text { 11. Université d'État des langues étrangères de } \\
\text { Nijni Novgorod Dobrolioubov * }\end{array}$ & 458 & 302 & 156 & 20 \\
\hline $\begin{array}{l}\text { 12. Université d'État des technologies de Moscou } \\
\text { Bauman }\end{array}$ & 450 & 0 & 450 & 7 \\
\hline 13. Université d'État de Penza & 428 & 220 & 228 & 15 \\
\hline 14. Université d'État de construction de Moscou & 400 & 0 & 400 & 5 \\
\hline 15. Université d'État de Voronej & 395 & 145 & 250 & 15 \\
\hline $\begin{array}{l}\text { 16. Université d'État des sciences humaines et } \\
\text { des technologies (Orekhovo-Zouïevo) }\end{array}$ & 380 & 300 & 80 & 9 \\
\hline 17. Université d'État de Koursk & 368 & 157 & 211 & 17 \\
\hline $\begin{array}{l}\text { 18. Université d'État des langues étrangères de } \\
\text { Piatigorsk }\end{array}$ & 362 & 105 & 257 & 25 \\
\hline 19. Université d'État de Toula & 342 & 65 & 277 & 14 \\
\hline $\begin{array}{l}\text { 20. Université fédérale du sud } \\
\text { (Rostov-sur-le-Don) }\end{array}$ & 327 & 125 & 202 & 16 \\
\hline 21. Université d'État de Tioumen & 318 & 171 & 147 & 20 \\
\hline $\begin{array}{l}\text { 22. Université pédagogique d'État de Russie } \\
\text { Herzen }\end{array}$ & 316 & 116 & 200 & 15 \\
\hline
\end{tabular}

* Données pour l'année 2017-2018 
периодически их обновлять (прежде всего в части новой терминологии).

Значительно уменьшилось и число самих вузовских преподавателей французского языка: их сегодня около 1800 человек (включая совместителей), половина из которых - члены Ассоциации преподавателей французского языка России (АПФЯ) 9 . В 2012 г. в ассоциацию входили 1200 человек (их уменьшение связано с общим сокращением числа преподавателей французского в РФ10).

АПФЯ вносит большой вклад в популяризацию французского языка среди российских школьников и студентов, участвует в проведении соответствующих конкурсов, фестивалей в различных городах России, организуетдля них языковые стажировки во Франции, проводит курсы повышения квалификации для преподавателей французского языка (140-150 человек в год, занятия ведут носители языка), а также а также различные семинары и конференции учебно-методического характера11. Так, АПФЯ провела с 26 января по 2 февраля 2020 г. очередной (XXIX) Всероссийский семинар преподавателей французского языка «Мир французского языка сегодня: новые знания, навыки, компетенции». Семинар был организован совместно с Агентством по международному образовательному сотрудничеству при поддержке Министерства просвещения и Министерства науки и высшего образования Российской Федерации и содействии Посольств Франции и других франкофонных государств в России.

Большуюучебно-методическую помощь как средним, так и высшим образовательным организациям России, имеющим программы изучения французского языка, оказывает Французский институт. Наиболее успешным в изучении французского языка студентам и школьникам предоставляется возможность лингвистических стажировок во Франции (путем конкурсного отбора и в форме предоставления стипендий), организуются мероприятия по повышению квалификации преподавателей французского языка как в России, так и во Франции (в рамках лингвистических стажировок и семинаров), предоставляется новая учебная литература по французскому языку, изданная во Франции.

Значимыми мероприятиями являются ежегодные съезды университетов-партнеров Французского института. Последний из них (XV) прошел в октябре 2019 г. на базе МГУ имени М.В. Ломоносова. Он был посвящен оцениванию в методике преподавания французского языка как иностранного. Съезды проходят в форме научно-практических конференций. Ежегодно в них участвуют до 250 преподавателей французского языка из партнерских университетов Посольства Франции в России. Данные съезды являются одним из основных мероприятий Франкоязычной лингвистической сети университетов-партнеров (Réseau Linguistique Francophone), в которую входят более 130 российских университетов.

Съезды преподавателей французского языка традиционно включаюттри вида мероприятий: обмен информацией о жизни сети партнерских университетов, а также обсуждение проблем академической мобильности и актуальных образовательных, лингвистических, академических и культурных событий во Франции и в России; научную конференцию по современным проблемам преподавания и изучения языков; мастер-классы от французских и российских экспертов по теме съезда.

Следует отметить значительный вклад в распространение французского языка в РФ и со стороны «Альянс Франсез», который имеет статус культурно-просветительской общественной некоммерческой организации, но работает под эгидой и при поддержке посольства Франции. «Альянс Франсез» начал свою деятельность в России в 2001 г., когда было открыто первое отделение организации (с участием Президента Франции Ж. Ширака) в Самаре. В последующие годы количество 
membres, la diminution de leur nombre est dû la diminution générale du nombre d'enseignants de français en Fédération de Russie ${ }^{10}$.

L'Association apporte une grande contribution à la popularisation du français parmi les écoliers et les étudiants en Russie, elle participe à l'organisation de concours de français, de festivals (dans différentes villes de Russie), organise des stages en France et également des formations pour les professeurs de français (140-150 par an, cours donnés par des locuteurs natifs), ainsi que différents séminaires et conférences à caractère didactique ${ }^{11}$.

Par exemple, l'Association a organisé du 26 janvier au 2 février 2020 son séminaire annuel (XXIXe édition) des professeurs de français de Russie autour de la thématique "Le monde du français aujourd'hui : vers de nouvelles connaissances, pratiques, compétences ". Il était organisé avec l'Agence de coopération internationale dans le domaine de l'enseignement avec le soutien du ministère de l'Instruction publique et de celui de la Science et de l'Enseignement supérieur et aussi la participation des ambassades de France et d'autres pays francophones en Russie.

L'institut français apporte une aide importante sur le plan des méthodes d'enseignement aux établissements scolaires et universitaires russes qui proposent des cours de français. Les meilleurs étudiants et écoliers ont la possibilité d'effectuer des stages en France par le moyen d'une sélection sur concours et l'attribution de bourses, et des formations pour les enseignants sont mises en place en Russie comme en France (dans le cadre de stages et séminaires), et des manuels actualisés édités en France sont fournis.

Les congrès annuels organisés par les universités partenaires de l'Institut français constituent aussi des étapes majeures. Le dernier d'entre eux (le XVe) s'est tenu en octobre 2019 à l'Université d'État de Moscou Lomonossov. Il était consacré à l'appréciation des méthodes d'enseignement du français comme langue étrangère. Les congrès se déroulent sous forme de conférences scientifiques et pratiques. Chaque année ils rassemblent jusqu'à 250 professeurs de français des universités partenaire de l'ambassade de France en Russie, ce sont les principales rencontres du Réseau linguistique francophone qui regroupe plus de 130 universités russes.

Les congrès de professeurs de français comprennent traditionnellement 3 types d'activités : des échanges d'informations sur la vie du réseau d'universités partenaires ainsi que des discussions sur les problèmes de mobilité académique et de rencontres en matière d'enseignement, de linguistique, académiques et culturelles en France et en Russie ; une conférence scientifique sur les problèmes d'enseignement et d'étude des langues aujourd'hui ; des master-classes réalisées par des experts français et russe sur la thématique choisie.

Il convient de noter la contribution significative apportée par l'Alliance française à la diffusion du français en Russie, elle a en effet le statut d'organisation à but non lucratif et à objectif culturel et de formation mais fonctionne sous l'égide et avec le soutien de l'ambassade de France. L'Alliance française a commencé son activité en Russie en 2001, c'est alors que fut inaugurée à Samara le premier bureau (avec la participation du président français Jacques Chirac). Dans les années qui ont suivi le nombre d'Alliances françaises en Russie a augmenté pour atteindre 13 et elles sont toujours actives dans les villes suivantes: Vladivostok, Ekaterinbourg, Irkoutsk, Kazan, Nijni Novgorod, Rybinsk (région de laroslavl), Perm, Rostov-surle-Don, Samara, Saratov, Togliatti et Oufa. En tant que centre culturels français 
представительств «Альянс Франсез» на территории РФ выросло до 13, и они действуют сегодня во Владивостоке, Екатеринбурге, Иркутске, Казани, Нижнем Новгороде, Рыбинске (Ярославская область), Перми, Ростове-на-Дону, Самаре, Саратове, Тольятти и Уфе. Эти представительства в качестве французских культурных центров организуют встречи с французскими артистами и учеными, дискуссии на различные культурные и литературные темы, обеспечивают доступ к художественной и учебной литературе, периодике, изданной на французском языке 12 , а также информируют о возможностях обучения во Франции ${ }^{13}$. В качестве образовательных центров они обучают (по французским программам и методикам, на платной основе) французскому языку, практикуются сеансы «языкового погружения»), проводят международные тесты и принимают экзамены (DELF, $D A L F, T C F, T E F$ и др.). Региональные «Альянс Франсез» также организуют для детей и молодежи 7-17 лет летние лингвистические лагеря (как правило, на базе местных домов отдыха, формируя группы учащихся по 10-12 человек, причем не по возрастному принципу, а исходя из их уровня владения языком).
Общее количество владевших русским языком во Франции составляло в 2018 г. по предварительной оценке 200 тыс. человек, или 0,4\% всего населения, что сопоставимо с долей россиян, владевших французским языком (0,4\% в 2010 г. и 2018 г.). Однако в образовательных организациях Франции число и удельный вес изучающих русский язык во много раз меньше, чем изучающих французский язык в школах, СПО и вузах России. Так, в системе среднего образования Франции русский язык в 2018/2019 г. изучали 12,8 тыс. человек (в 169 лицеях и колледжах), или 0,1\% всех учащихся, и их число на протяжении последних 25 лет постепенно сокращается (в 1995/1996 учебном году русский язык учили в средних образовательных организациях 18,8 тыс. чел.). В системе высшего образования Франции русский язык учат сегодня примерно 5,5 тыс. студентов (программы изучения русского языка имеются в 26 университетах, а также ряде высших школ). Дисбаланс и определенные проблемы с распространенностью французского языка в России и русского во Франции требуют принятия серьезных согласованных мер с российской и французской стороны, прежде всего в рамках систем образования.

\section{Примечания}

${ }^{1}$ Составлено по данным переписи населения Российской Федерации в 2002 и 2010 гг.

2 Составлено по данным Министерства образования и науки и Министерства просвещения РФ за соответствующие годы.

з Составлено по: Образование в России - 2017, 2018, 2019. Статистический бюллетень. М.: МИРЭА-Моск. технолог. ун-т, 2017-2019.

4 Составлено по данным Рособрнадзора. Режим доступа: http://obrnadzor.gov.ru/ru/ press_center/news/index.php?id_4=4888

5 Там же.

б Является подразделением посольства Франции в России и имеет офисы в Москве и в Санкт-Петербурге. 
ces bureaux de l'Alliance française organisent des rencontres avec des artistes et des scientifiques français, des discussions sur différents thèmes à caractère culturel ou littéraire, ils assurent l'accès à de la littérature artistique et didactique, à des périodiques en français 12 , ils procurent également des informations sur les possibilités de poursuivre des études en France ${ }^{13}$. En qualité de centres de formation ils assure un apprentissage la langue (selon les programmes et méthodes français, sous forme payante), des séances d'« immersion linguistique " sont organisées, de même que des tests et des examens internationaux de français (DELF, DALF, TCF, TEF, etc.). Les bureaux régionaux de l'Alliance française organisent aussi pour les jeunes de 7 à 17 ans des camps d'été de pratique de la langue, en général sur la base des maisons de repos locales en constituant des groupes de 10-12 personnes, non pas par âge mais en fonction du niveau de connaissance de la langue.

Le nombre total de personnes maîtrisant le russe en France était estimé en 2018 à 200 000, soit environ 0,4\% de la population, ce qui est comparable à la part de Russes connaissant le français (0,4\% en 2010 et estimé à autant en 2018). Cependant, dans les établissements d'enseignement en France le nombre et la part des personnes étudiant le russe est bien inférieure à ceux des personnes étudiant le français dans les écoles et universités en Russie. Ainsi, dans le système d'enseignement en France la langue russe pour l'année 2018-2019 était étudiée par 12800 personnes (dans 169 collèges et lycées), soit 0,1\% de tous les étudiants et leur nombre depuis les 25 dernières années ne cesse de se réduire (en 1995-1996 le russe était étudié dans l'enseignement secondaire par 18800 personnes). Dans le système de l'enseignement supérieur en France le russe est étudié aujourd'hui par environ 5500 étudiants (26 universités et grandes écoles proposent des programmes de russe). Le déséquilibre et les problèmes manifestes de diffusion du français en Russie et du russe en France nécessite la prise de mesures concertées de la part de la France et de la Russie, d'abord dans le cadre des systèmes d'enseignement nationaux.

\section{Endnotes}

1 D'après les recensements réalisés en Fédération de Russie en 2002 et 2010.

2 D'après les données des ministères russes de l'Enseignement et de la Science, et de l'Instruction publique pour les années correspondantes.

3 D'après : L'enseignement en Russie 2017, 2018, 2019. Bulletin statistique, Moscou, MIERA-Université des technologies de Moscou, 2017-2019.

4 D’après l'agence Rosobrnadzor, voir http://obrnadzor.gov.ru/ru/press_ center/news/index.php?id_4=4888

5 D'après l'agence Rosobrnadzor, voir http://obrnadzor.gov.ru/ru/press_ center/news/index.php?id_4=4888

${ }^{6}$ Département de l'ambassade de France en Russie qui a des bureaux à Moscou et à Saint-Pétersbourg. 
7 Составлено по результатам мониторингов изучения иностранных языков в образовательных организациях России, проводившихся в 2008 и 2019 гг. под руководством автора.

8 Федеральное агентство по образованию, существовавшее в 2004-2010 гг., имевшее более 340 подведомственных вузов.

${ }^{9}$ Ассоциацию с 1992 г. возглавляет Жанна Михайловна Арутюнова, профессор РуДН, член-корреспондент Международной академии наук педагогического образования, основатель кафедры французского языка в Российском государственном гуманитарном университете, которой руководила с 1993 по 2013 г. Имеет ряд правительственных наград Франции.

10 Часть преподавателей французского языка переходит (после переквалификации) на преподавание английского языка, другие вообще покидают образовательные учреждения.

${ }^{11}$ Мероприятия АПФя (ежегодные курсы повышения квалификации, учебные семинары) в последние годы проходят в Подмосковье на базе учебного центра «Доброе» Российского государственного социального университета.

12 «Альянс Франсез» имеет в своем распоряжении медиатеку, где можно найти современную и классическую французскую литературу, учебно-методические пособия, газеты и журналы на французском и русском языках, фильмы, музыкальные диски.

13 «Альянс Франсез» также предоставляет возможность пройти стажировку во Франции сроком до трех месяцев в сфере гостиничного и ресторанного дела и предоставляет информацию о долгосрочном обучении во Франции. 
7 D'après différentes enquêtes sur l'étude des langues étrangères dans les établissements d'enseignement en Russie effectuées sous la direction de l'auteur en 2008 et 2019.

${ }^{8}$ Agence fédérale de l'enseignement, ayant existé de 2004 à 2010, avec plus de 340 établissements sous son autorité.

9 L'Association est dirigée depuis par Jeanna Aroutiounova, professeur de l'Université russe de l'Amitié entre les peuples, membre correspondant de l'Académie internationale des sciences de l'enseignement, fondatrice de la chaire de français qu'elle a dirigée de 1993 à 2013 à l'Université d'État des sciences humaines. Honorée de nombreuses récompenses et médailles françaises.

10 Une partie des enseignants de français passe (après reconversion) à l'enseignement de l'anglais, d'autres quittent les établissements d'enseignement.

${ }^{11}$ Les rencontres de l'Association des professeurs de français de Russie (formations annuelles, séminaires) se déroulent ces dernières années dans la région de Moscou sur la base du centre de formation "Dobroïé " de l'Université sociale d'État de Russie.

12 Les Alliances françaises disposent de médiathèques proposant de la littérature française classique et contemporaine, des manuels, des journaux et magazines en français et en russe, des films et des disques.

13 L'Alliance française propose aussi la possibilité de suivre des stages en France jusqu'à 3 mois dans le domaine de l'hôtellerie-restauration et fournit des informations sur les études longues en France. 